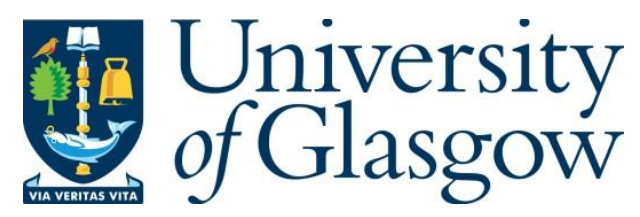

Docherty, C. K., Harvey, K. Y., Mair, K. M., Griffin, S., Denver, N. and MacLean, M.

R. (2018) The role of sex in the pathophysiology of pulmonary hypertension. In:

Kerkhof, P. L.M. and Miller, V. M. (eds.) Sex-Specific Analysis of Cardiovascular

Function. Series: Advances in experimental medicine and biology (1065). Springer:

Cham, pp. 511-528. ISBN 9783319779317.

There may be differences between this version and the published version. You are advised to consult the publisher's version if you wish to cite from it.

http://eprints.gla.ac.uk/166663/

Deposited on: 15 August 2018

Enlighten - Research publications by members of the University of Glasgow http://eprints.gla.ac.uk 


\section{The role of sex in the pathophysiology of pulmonary hypertension}

Craig K Docherty, Katie Yates Harvey, Kirsty M Mair, Sinead Griffin, Nina Denver, \& Margaret R MacLean.

Research Institute of Cardiovascular and Medical Sciences, College of Medical, Veterinary and Life Sciences, University of Glasgow.

Corresponding Author:

Margaret R MacLean

Research Institute of Cardiovascular and Medical Sciences

College of Medical, Veterinary and Life Sciences

Room 448

West Medical Building/Wolfson Link Building

University of Glasgow

G12 8QQ

phone: + 44 (0) 1413304768

fax: + $44(0) 1413305481$

Email mandy.maclean@glasgow.ac.uk 


\section{Abstract}

Pulmonary arterial hypertension (PAH) is a progressive disease characterised by increased pulmonary vascular resistance and pulmonary artery remodelling as result of increased vascular tone and vascular cell proliferation, respectively. Eventually, this leads to right heart failure. Heritable PAH is caused by a mutation in the bone morphogenetic protein receptor-II (BMPR-II). Female susceptibility to PAH has been known for some time and most recent figures show a female: male ratio of 4:1. Variations in the female sex hormone estrogen and estrogen metabolism modify FPAH risk and penetrance of the disease in BMPR-II mutation carriers is increased in females. Several lines of evidence point towards estrogen being pathogenic in the pulmonary circulation and thus increasing the risk of females developing PAH. Recent studies have also suggested that estrogen metabolism may be crucial in the development and progression of PAH with studies indicating that downstream metabolites such as $16 \alpha$-hydroxyestrone are up-regulated in several forms of experimental pulmonary hypertension (PH) and can cause pulmonary artery smooth muscle cell proliferation and subsequent vascular remodelling. Conversely, other estrogen metabolites such as 2methoxyestradiol have been shown to be protective in the context of PAH. Estrogen may also upregulate the signalling pathways of other key mediators of PAH such as serotonin.

Key words: Pulmonary arterial hypertension, vascular remodelling, sex hormones, estrogen, estrogen metabolites, serotonin. 


\section{Introduction}

Pulmonary arterial hypertension (PAH) is a debilitating disease characterised by an increase in pulmonary artery pressure and pulmonary vascular resistance. The World Health Organization (WHO) categorises PAH patients into five distinct functional classifications

(Table 1) (Simonneau et al., 2013).

Table 1: Clinical classification of pulmonary hypertension.

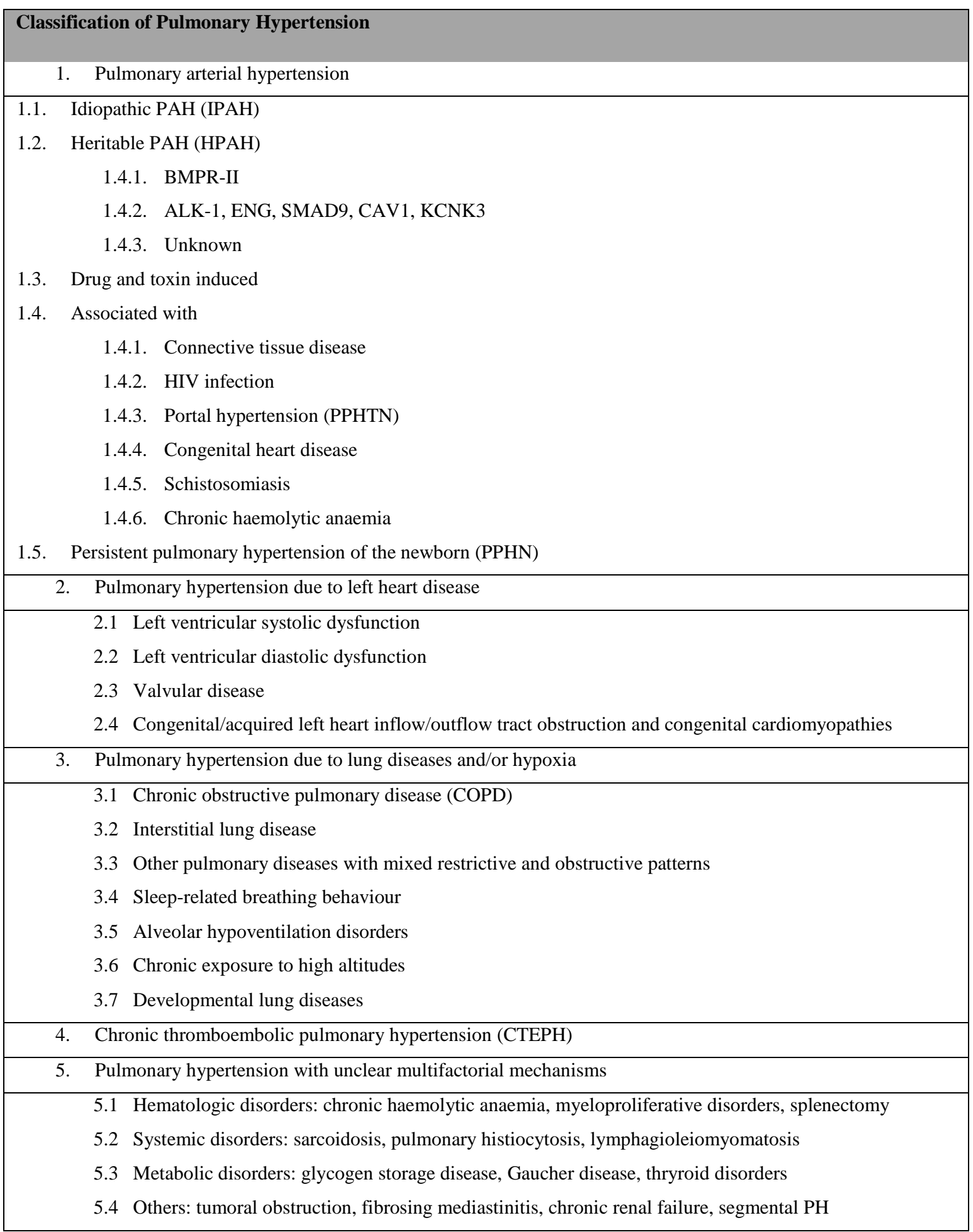


Occurrence of both idiopathic and familial PAH ranges from 6-10 cases per million in the population whereas the number of those patients developing PAH as a result of other illness is estimated to be much higher, although not reported (Barst, 2008). PAH is an incurable vasculopathy which affects the arteries of the pulmonary circulation and contributes to the morbidity and mortality of adult and paediatric patients with a wide range of lung and heart diseases. PAH is characterized by a progressive obstruction of distal pulmonary arteries and formation of plexiform lesions leading to elevated pulmonary vascular pressures and right heart failure. The pathogenesis of PAH is complex and involves numerous pathophysiological phenotypes including pulmonary artery endothelial cell (PAEC) dysfunction, pulmonary artery smooth muscle cell (PASMC) proliferation, apoptotic resistance, metabolic shift (Warburg effect), impaired angiogenesis, phenotypic transition and chronic inflammation (Tuder et al., 2013, Humbert et al., 2008, Rabinovitch, 2012).

The non-specific nature of early PAH symptoms, including dizziness, syncope and fatigue often leads to delayed diagnosis, definitively by invasive right heart catheterisation (Montani et al., 2013). Consequently, patient's exhibit more advanced pathophysiological features and therefore a lower quality of life. To date there is no known cure for PAH although there are a number of treatment options available targeting the main pathways involved in the pathogenesis of PAH.

\section{Endothelin receptor antagonists}

Endothelin 1 (ET- 1) is a 21 amino acid, vasoactive peptide. Under physiological conditions, ET-1 is produced in small amounts, mainly in endothelial cells, acting as an autocrine/paracrine mediator. The biological effects of ET-1 are transduced by two receptor subtypes, the $\mathrm{ET}_{\mathrm{A}}$ and $\mathrm{ET}_{\mathrm{B}}$ receptors. In the vasculature, the $\mathrm{ET}_{\mathrm{A}}$ receptor is mainly located on vascular smooth muscle cells, whilst $\mathrm{ET}_{\mathrm{B}}$ receptors are localized on both endothelial and vascular smooth muscle cells. Activation of $\mathrm{ET}_{\mathrm{A}}$ and $\mathrm{ET}_{\mathrm{B}}$ receptors on vascular smooth muscle results in vasoconstriction (Seo et al., 1994, McCulloch et al., 1996). The activation of endothelial $\mathrm{ET}_{\mathrm{B}}$ receptors located on the endothelium stimulates the release of nitric oxide (NO) and prostacyclin (Hirata et al., 1993) prevents apoptosis and plays a minor role in endothelial-dependent vasodilatation (Shichiri et al., 1997). The lungs are the major site for both clearance and production of circulating ET-1: up to 50\% of circulating ET-1 is cleared through the $\mathrm{ET}_{\mathrm{B}}$ receptors (Dupuis et al., 1996). 
In PAH an upregulation of the ET-1 system occurs. ET-1 plasma levels are elevated and the increase is correlated with right atrial pressure, pulmonary artery oxygen saturation and pulmonary vascular resistance (Stewart et al., 1991). ET-1 pre-cursor, prepro-ET-1, is also abundantly over-expressed in endothelial cells from patients with PAH (Giaid et al., 1993) and stimulates proliferation of PASMCs and vasoconstriction (Wort et al., 2001). ET-1 receptor antagonists, bosentan, macitentan and ambrisentan are currently approved for the treatment of PAH, preventing the aberrant activity of ET-1 observed in patients. Bosentan and macitentan are dual $\mathrm{ET}_{\mathrm{A}}$ and $\mathrm{ET}_{\mathrm{B}}$ receptor antagonist, whereas ambrisentan is a selective $\mathrm{ET}_{\mathrm{A}}$ receptor antagonist (Correale et al., 2013).

\section{Prostacyclin Analogues}

Prostacyclin is a member of the eicosanoid family of mediators, which include prostaglandins, thromboxanes and leukotrienes. It is a potent vasodilator and inhibitor of platelet aggregation. Prostacyclin is synthesised from arachidonic acid by the actions of cyclo-oxygenase and prostacyclin synthase, primarily in endothelial cells. In PAH dysregulation of prostacyclin metabolic pathways occurs. A reduction in prostacyclin levels are observed, characterised by a decrease in urinary metabolites (Christman et al., 1992) and a decrease in prostacyclin synthase expression in the lungs of PAH patients (Tuder et al., 1999). Several prostacyclin analogues including epoprostenol, iloprost and treprostinil are used clinically in the treatment of PAH (Galie et al., 2009). In addition to their vasodilator properties, prostacyclin analogues can also have inhibitory effects on PASMC proliferation and migration (Clapp et al., 2002). Hence, prostacyclin agonists and analogues are used to treat severe PAH. The most recent member of this drug class, selexipag, a selective prostacyclin receptor agonist, was approved by the Food and Drug Administration (FDA) for PAH in 2015 (Lau et al., 2017, Sharma, 2015).

\section{Phosphodiesterase - 5 (PDE-5) inhibitors}

The cyclic nucleotides, cyclic adenosine monophosphate (cAMP) and cyclic guanosine monophosphates (cGMP) are important mediators of pulmonary vasodilation via activation of protein kinase A (PKA) and protein kinase G (PKG), respectively (Montani et al., 2014). NO is a well-established mediator involved in activation of the cGMP pathway.

Phosphodiesterase's (PDEs) catalyse the hydrolysis of cAMP and cGMP and promote vasodilation by increasing the concentration of both cyclic nucleotides intracellularly. PDE-5 is cGMP selective and is highly expressed in the lung (MacLean et al., 1997). Inhibitors of 
PDE5 promote vasodilation via cGMP and are effective in PAH management. PDE5 inhibitor drugs approved for the treatment of PAH include sildenafil, tadalafil and vardenafil (Rashid et al., 2017, Gao et al., 2017).

\section{Soluble guanylate cyclase stimulator}

Soluble guanylate cyclase (sGC) is the primary NO receptor. On binding to NO, sGC catalyses the synthesis of cGMP, which promotes vasodilation but also inhibits vascular smooth muscle cell proliferation, leukocyte recruitment, platelet aggregation and vascular remodelling. There is dysregulation of NO production, sGC activity and cGMP degradation in PAH (Stasch and Evgenov, 2013). This enzyme is a direct target to activate NO- sGC)cGMP pathway and targeting of sGC stimulation by riociguat has consistently improved response to exercise following treatment in pulmonary hypertension patients (Lian et al., 2017). This occurs via vasodilation within the pulmonary arterial bed thus improving hemodynamics and vascular tone.

\section{Sex as a risk factor in PAH}

In the 1950's, Dresdale first documented an increased frequency of female PAH patients compared to men (Dresdale et al., 1951). The increased prevalence of PAH in females remains; evidenced by recent epidemiological studies highlighting that $70-80 \%$ of $\mathrm{PAH}$ patients are female (Badesch et al., 2010). This is in contrast to other demographics, which have changed over time i.e. age of diagnosis ranges from 50-65 years in contemporary registries compared to 36 years previously reported (Hoeper and Gibbs, 2014). As the age of diagnosis has increased, patients are presenting with more co-morbidities, and are therefore more difficult to manage clinically. However, reasons underlying the imbalanced female to male ratio regarding disease prevalence remain obscure. Conversely, male PAH patients exhibit poorer survival than female patients (Jacobs et al., 2014), leading to investigation of the phenomenon known as the 'sex paradox' in pulmonary hypertension. Recent studies suggest that males have poorer adaptive remodeling of the right ventricle (RV) in response to increased afterload - this may explains sex differences in survival in PAH (Jacobs et al., 2014). Such paradoxical observations suggest a role for complex sex hormone signaling and processing pathways in the development and progression of PAH (Foderaro and Ventetuolo, 2016). This sex paradox also seems to be dependent on the age of PAH patients with the age of onset being earlier in women than men, perhaps due to altered estrogen production at 
menopause. The influence of sex hormones in women presenting with $\mathrm{PAH}$ is further suggested by the onset of PAH during pregnancy and/or post-partum period (Terek et al., 2013). While treatment guidelines now suggest that female PAH patients do not take estrogen-based contraceptives (Hemnes et al., 2015), current PAH therapies do not take sex bias into account despite recent studies having shown sex differences in treatment response (Gabler et al., 2012, Shapiro et al., 2012). For example, Gabler and colleagues reported that ET-1 receptor antagonists had greater efficacy in females than males (Gabler et al., 2012). A more recent study found increased likelihood of response to PDE5 inhibitor, tadalafil in the treatment of PAH, in men compared with women (Mathai et al., 2015). Sex-specific heterogeneity in treatment response may reflect differences in PAH pathobiology, and afford the opportunity to inform individual treatment decisions and provide the basis for exploring potential differences in mechanisms of disease between sexes.

\section{Sex differences in the BMPR-II signalling pathway in pulmonary hypertension}

Bone morphogenic protein (BMP) receptor type II (BMPR-II) is a serine/threonine transmembrane type II receptor kinase, belonging to the transforming growth factor (TGF)- $\beta$ super family. BMPR-II is involved in processes such as development, embryogenesis and adult tissue homeostasis. BMP ligands cause the formation of a heterodimer between BMPRII and a type I receptor. Following heterodimer formation and the phosphorylation of the type I receptor there is phosphorylation of Smad 1/5/9 proteins which in turn leads to the upregulation of expression of nuclear Inhibitor of Differentiation 1 and 3 (Id1/Id3), both Id1/Id3 act to repress proliferation. The proliferation, migration and apoptosis of both endothelial cells and smooth muscle cells within the vasculature can be influenced by BMP signalling (Garcia de Vinuesa et al., 2016). Mutations in the gene encoding for BMPR-II is the most well established risk factor for heritable PAH. Over 300 different mutations sites within the BMPR-II gene have been identified in PAH patients and are associated with PAH development and progression. Approximately $75 \%$ of familial PAH cases and $20 \%$ of idiopathic PAH cases are associated with a loss-of-function mutation in this gene (Machado et al., 2009). The penetrance of BMPR-II mutations are particularly low, only approximately $20 \%$ of male carriers develop PAH whilst approximately $45 \%$ of female carriers develop the disease (Newman et al., 2004). Therefore, other genetic and environmental risk factors must 
exist. Alternative splicing of BMPR2 is thought to play a role in the penetrance of the disease. BMPR-II can be alternatively spliced producing 2 different isoforms - the full transcript and one lacking exon 12. Exon 12 is the largest exon within BMPR-II and encodes a cytoplasmic domain (Machado et al., 2006). The ratio of the isoform-B to isoform-A is increased in PAH patients when compared to unaffected BMPR-II mutation carriers. Therefore is has been suggested that expression of isoform B is involved in the penetrance of the disease (Cogan et al., 2012).

A reduction in BMPR-II signalling and therefore a reduction in the anti-proliferative Id1/3 leads to increased proliferation of the PASMCs (Morrell et al., 2009) and subsequent pathological remodelling of the pulmonary vasculature. It has been demonstrated that PAH patients harbouring a BMPR-II mutation develop the disease at an earlier age and have worse hemodynamic profiles at the time of diagnosis than those patients without a BMPR-II mutation. As a result, BMPR-II mutation carriers have an increased mortality (Evans et al., 2016).

It is well established that a greater number of females develop PAH. There are sex specific differences in the expression and activity of BMPR-II, even under basal conditions, which could contribute to the greater number of females within the PAH patient population. Female PASMCs obtained from non-PAH subjects have been shown to have reduced expression of BMPR-II at both a gene and protein level when compared to male PASMCs obtained from non-PAH subjects (Mair et al., 2015). Furthermore, the downstream factors in the BMPR-II signaling pathway, Smad 1 and Id1/3, were also down regulated in female PASMCs. This suggests that females could be pre-disposed to PAH because they have basally lower levels of BMPR-II. Interestingly, when male non-PAH PASMCs were stimulated with estrogen, no changes were observed in the expression of BMPR-II and Smad 1, yet there was a reduction in mRNA and protein levels of the Id genes (Mair et al., 2015). Therefore, estrogen could be responsible for driving the suppression of the BMPR-II pathway and the predisposition of females to PAH. Other sex specific differences in BMPR-II expression have been highlighted in PAH patients. BMPR-II gene expression in lymphocytes was approximately $20 \%$ lower in female patients than in male patients (Austin et al., 2012). When comparing whole lung BMPR-II expression in male and female mice, BMPR-II gene expression was lower in the female, compared to male mouse. The same study also highlighted an estrogen response element (ERE) in the BMPR-II promotor. This ERE was found to be a highly conserved functional binding site for estrogen receptor alpha (ER $\alpha$ ) (Austin et al., 2012). Therefore, it is 
suggested that estrogen is able to reduce expression of BMPR-II through the direct binding of ER $\alpha$ to the BMPR-II promoter. In addition, we have demonstrated decreased BMPR-II signalling in lungs from the sugen-hypoxic rat model of pulmonary hypertension (Mair et al., 2014b). Inhibition of estrogen synthesis with an aromatase inhibitor reversed the experimental pulmonary hypertension in the female rats and restored the deficient BMPR-II signalling (Mair et al., 2014b), suggesting that endogenous estrogen can supress BMPR-II signalling in vivo. This strengthens the hypothesis that estrogen can cause sex specific differences in BMPR-II expression, which ultimately results in the predisposition of females to PAH. Despite dysfunctional BMPR-II signalling being well characterised in the lung, the downstream effects in the RV are not well understood. A recent clinical study suggested BMPR-II mutation carriers have poorer RV function despite similar afterload and cardiac adaptation in mutation carrier and non-carrier groups (van der Bruggen et al., 2016). This study suggests that BMPR-II signalling can influence RV dysfunction in PAH. Currently, little is known regarding sex specific differences in BMPR-II expression in the RV and the potential effects this might have on RV function in PAH.

\section{The influence of sex hormones in pulmonary hypertension}

A recent comprehensive study by Ventetuolo and colleagues characterised the relationship of sex and hemodynamics in PAH (Ventetuolo et al., 2014). Ventetuolo et al, also recently demonstrated robust clinical data outlining significantly increased plasma estrogen levels in male idiopathic PAH patient's vs control subjects (Ventetuolo et al., 2016a). Differential effects of estrogen on the pulmonary circulation and RV and/or differential metabolism of estrogen to mitogenic or anti-proliferative metabolites may well explain the differences observed in outcomes of animal models as well as the notable sex difference in the incidence of the disease.

One hypothesis that may explain the female susceptibility in PAH is that the female hormone estrogen is pathogenic in the pulmonary circulation. The estrogen pathway is known to be affected in diseases such as systemic lupus erythematosus and breast cancer, both of which have a higher female prevalence (Ohta et al., 2013). Progesterone, testosterone, DHEA, as well as estrogen and metabolites have been shown to affect pulmonary vascular tone and cell proliferation (Lahm et al., 2014). Male rodents with hypoxia- or monocrotaline-induced PH develop more severe experimental PH than females whilst there is no sex-bias in 
Sugen/hypoxic rodent models (Umar et al., 2012, Mair et al., 2014a). In experimental models of PH (hypoxia-induced and monocrotaline-induced) where male animals are dosed with exogenous estrogen, this exerts protective, vasodilatory and anti-proliferative effects (Lahm et al., 2012). Exogenously administered estrogen can improve RV function in the Sugen/hypoxic model of PH by stimulating RV contractility and protecting against pulmonary vascular remodelling (Liu et al., 2014). However, inhibiting endogenous estrogen with an aromatase inhibitor reverses sugen/hypoxic-induced PH in females and in BMPR2 mutant mice without affecting RV function implying that local endogenous estrogens are protective (Mair et al., 2014b, Dean et al., 2016, Chen et al., 2017). However, eliminating endogenous circulating estrogen via ovariectomy also abolishes the PH phenotype in femalesusceptible transgenic mice including serotonin transporter (SERT) overexpressing (SERT+)

mice (White et al., 2011), Smad1 ${ }^{+/-}$mice (Mair et al., 2015) and dexfenfluramine-treated mice (Dempsie et al., 2013).

\section{The role of sex hormones and sex hormone metabolites in pulmonary arterial hypertension}

\section{Estrogen Biosynthesis and Metabolism}

The female sex hormones are steroid hormones that comprise both estrogens and progesterones. Steroid hormones have multi-factorial functions throughout the body and are synthesized from cholesterol in the gonads, adrenal glands and placenta and to a lesser extent in the adipose tissue, liver and skin (Knowlton, 2012). Estrogens are the primary female sex hormone involved in development and maintenance of the female reproductive system. Evidence also exists for a significant role for estrogens in other systems including the cardiovascular system (Knowlton, 2012). Such that, synthesis of estrogen can also take place in liver and adipose tissue and the reported expression of estrogen-synthesising enzymes in vascular smooth muscle cells and endothelial cells (Tofovic, 2010) implicates the importance of 'local' estrogen synthesis and autocrine/paracrine effects out with the reproductive organs.

Estrogens exist as three major naturally occurring isoforms: estrone, estrogen and estriol. Estrogen is the predominant circulating hormone in pre-menopausal women, whilst estrone is important during the menopause and estriol during pregnancy. In the follicular phase, 
circulating concentrations of estrogen are about $\sim 0.4 \mathrm{nM}$ and during ovulation these levels rise to $\sim 2.2 \mathrm{nM}$. After menopause, estrogen levels are reduced up to 20-fold (Mendelsohn and Karas, 1999). The biosynthesis of estrogen is initiated by the synthesis of androstenedione from the precursor cholesterol. Androstenedione provides an intermediate stage in metabolism from which estrogen can be synthesised by cytochrome P450 enzyme (CYP) 19A1 (aromatase) which converts androstenedione to estrone, which in turn is converted to estrogen by $17 \beta$ hydroxysteroid dehydrogenase 1 (17ßHSD1). Alternatively, reduction of androstenedione to testosterone, can occur via $17 \beta$ hydroxysteroid dehydrogenase 2 (17ßHSD2), followed by aromatisation of testosterone to estrogen.

As a predominantly female hormone, estrogen is assumed detrimental in generating the high prevalence of female PAH patients. For example, polymorphisms in aromatase, the estrogen synthesising enzyme, and the gene for $\mathrm{ER} \alpha(\mathrm{Esrl})$, are associated with elevated estrogen levels in the lungs of female patients and predispose to porto-pulmonary hypertension (Roberts et al., 2009, White et al., 2012). In agreement, heightened exposure to exogenous estrogen through both use of oral contraceptives and hormone replacement therapy is associated with PAH (MASI, 1976). On the contrary, there is evidence to suggest hormone replacement therapy can prevent the development of PH in patients with systemic sclerosis (Beretta et al., 2006).

\section{Aromatase}

Certain tissues can modulate their own estrogenic milieu by the local conversion of testosterone or androstenedione to estrogen and estrone, by the activity of aromatase which is expressed within the pulmonary arteries (Harada et al., 1999, Mair et al., 2014b). Circulating aromatase precursors act as a reservoir for the synthesis of estrogens within extra-gonadal sites, namely; androstenedione, dehydroepiandrosterone (DHEA) and DHEA-sulphate (DHEA-S) (Simpson, 2003). Locally synthesised estrogens can act in a paracrine or autocrine fashion creating a potentially potent estrogenic milieu that may be superior to the effects of circulating levels. The aromatase gene is present in gonadal and extra-gonadal tissues with its site-specific transcription being driven by different signaling pathways at alternative sites in the promoter region. 
Expression of aromatase has also been defined within lung tissue giving rise to the presence of a local pulmonary vasculature estrogenic microenvironment. The aromatase inhibitor anastrozole has shown remarkable therapeutic potential in the Sugen5416-hypoxic rat model and hypoxic rat model where it successfully reversed the PH phenotype in female rats and this correlated with reduced plasma estrogen levels and restored BMPR-II signaling (Tofovic and Jackson, 2013, Mair et al., 2014b). Inhibition of aromatase, by anastrozole is now widely recognised for use in estrogen sensitive breast cancer (Forbes et al., 2008). The therapeutic potential in PAH of anastrozole, has very recently been shown to be safe and effective in a small proof of concept study (Kawut et al., 2016), where anastrozole significantly reduced estrogen levels and improved 6-minute walk distance (6MWD). These results are promising and suggest that longer and larger Phase II trials of anastrozole are warranted.

\section{Oxidative Metabolism of Estrogens: Cytochrome P450 Enzymes}

Estrogen can be rapidly metabolised by oxidation. Oxidative metabolism occurs primarily in the liver producing non-Estrogenic metabolites ready for elimination from the body. Estrogen and estrone are in equilibrium with $17 \beta \mathrm{HSD} 1$, and oxidation/reduction occurs at the carbon (C)-17 position and favours formation of estrone. Further metabolism of estrogen occurs, for example, at the $\mathrm{C} 16, \mathrm{C} 4$ and $\mathrm{C} 2$ positions producing biologically active metabolites, including 16 $\alpha$-hydroxyestrone (16 $\alpha \mathrm{OHE1})$. CYPs contain an iron $\left(\mathrm{Fe}^{3+}\right)$ docking site for oxygen, which in the presence of NADPH is reduced $\left(\mathrm{Fe}^{2+}\right)$. CYP enzymes are critically involved in xenobiotic metabolism, as well as metabolism of eicosanoids, steroids and cholesterol synthesis, amongst others. Metabolism by the activity of CYP enzymes has a genotoxic capacity via the generation of reactive oxygen intermediates that can interact with nucleic acids and proteins and initiate tumorigenesis (Nebert and Dalton, 2006). Specifically, CYP1A1, CYP1A2, CYP1B1, and CYP3A4 appear critical in the formation of 2- and 4hydroxy-derivatives of estrogen. The 2-hydroxylation pathway is the major metabolic pathway in the liver whereas 4-hydroxylation constitutes a relatively minor pathway. The 2and 4-hydroxy-derivatives are then further converted/deactivated to 2- and 4-methoxy metabolites by the catechol-O-methyltransferase (COMT), reducing the capacity to redox cycle/generate quinones and semiquinones. In a regulatory feedback mechanism, estrogen can promote its own breakdown by driving the transcription of the human CYP1B1 gene via an ERE in the promoter region (Tsuchiya et al., 2005). 


\section{CYP1B1 in PH}

There is evidence that CYP1B1 may play an important role in the pathogenesis of PAH. CYP1B1 is highly expressed in pulmonary arteries from patients with PAH and the CYP1B1 inhibitor, 2,3',4, 5'-tetramethoxystilbene (TMS) can reverse $\mathrm{PH}$ in sugen/hypoxic and hypoxic models of PH (White et al., 2012b). In addition it increases survival in the monocrotaline rat model of pulmonary hypertension (Johansen et al., 2016). TMS also abolished estrogen-induced proliferation in hPASMCs from controls and patients (White et al., 2012a). Genetic polymorphisms in CYP1B1 and the estrogen metabolites produced by this enzyme have also been identified as factors influencing the penetrance of the disease in individuals with BMPR-II mutations (Austin et al., 2009). Indeed a CYP1B1 SNP in tight linkage disequilibrium with SNPs associated with pulmonary hypertension has been identified, suggesting these pathways may underpin sexual dimorphism in RV failure (Ventetuolo et al., 2016b).

Serotonin and dexfenfluramine can also increase the expression of CYP1B1 in PASMCs (Johansen et al., 2016, White et al., 2011, Dempsie et al., 2013). Indeed, TMS and/or CYP1B1 deletion in mice reverses the development of PH in SERT+ mice or dexfenfluramine-treated mice (Dempsie et al., 2013, Johansen et al., 2016). Dexfenfluramine up-regulated expression of CYP1B1 in PASMCs from PAH patients and dexfenfluraminemediated proliferation these cells was ablated by the CYP1B1 inhibitor, TMS. Estrogen also increased expression of CYP1B1 in PAH-derived PASMCs (Dempsie et al., 2013).

The enzyme CYP1B1 is involved in both the metabolism of estrogen, and arachidonic acid. In the lungs, epoxyeicosatrienoic acids (EETs) and hydroxyeicosatetraenoic acids (HETEs) have inflammatory and mitogenic effects. 20-HETEs increase NADPH oxidase (Nox)derived reactive oxygen species (ROS) production in bovine PAECs (Medhora et al., 2008, Choudhary et al., 2004) and are implicated in the development of hypoxic PH (Zhu and Ran, 2012). Notably, EETs have opposite effects in the systemic circulation, which may explain the plausible divergent effects of estrogen in the systemic versus the pulmonary circulation (Zhu and Ran, 2012). 


\section{6a-hydroxyestrone in the development of PH}

$16 \alpha \mathrm{OHE} 1$ has been shown to be a biologically active and significantly more estrogenic than estrogen at the classical estrogen receptors ER $\alpha$ and ER $\beta$ (Mueck et al., 2002, Austin et al., 2012). Urinary levels $16 \alpha \mathrm{OHE} 1$ were elevated in a hypoxia-induced PH model and, when administered to mice, $16 \alpha \mathrm{OHE} 1$ caused a significant increase in RV hypertrophy (RVH), pulmonary artery remodeling and RV systolic pressure (RVSP) (White et al., 2012). $16 \alpha \mathrm{OHE} 1$ also induced proliferation in PASMCs confirming this pro-proliferative phenotype in the human setting (White et al., 2012). Indeed, an increase in plasma 16 $\alpha$ OHE1 levels have been demonstrated in 4,40 -Methylenedianiline (DAPM)- induced PH in rats providing further evidence for a role for $16 \alpha \mathrm{OHE} 1$ in the development of experimental PH (CarrollTurpin et al., 2015). Austin et al., (2009) established a link between altered estrogen metabolism and penetrance in heritable PAH. Here, a decreased ratio of 2hydroxyestradiol/16 $\alpha \mathrm{OHE} 1$ was observed in affected BMPR-II mutation carriers vs unaffected BMPR-II mutation carriers, thus suggesting a shift to the pro-proliferative phenotype observed in heritable PAH (Austin et al., 2009). The molecular mechanism for $16 \alpha \mathrm{OHE} 1$-induced proliferation appears to be complex and is at least in part, mediated by ROS. 16 $\alpha \mathrm{OHE} 1$ induces superoxide and hydrogen peroxide production and downregulates the protective effects of Nuclear factor erythroid-derived like factor 2 (Nrf-2) through Nox1 and ER $\alpha$ (Hood et al., 2016). Together, these studies further emphasize the potential role $16 \alpha \mathrm{OHE} 1$ may play in the development of PAH.

\section{2-methoxyestradiol as an anti-proliferative metabolite}

There is an increasing body of evidence suggesting that some estrogen metabolites can be protective in the setting of PAH. The 2-methoxyestrogens are perhaps the best example of the estrogen metabolites known to have beneficial effects in the pulmonary vasculature. Indeed, 2-methoxyestradiol (2ME2) has been studied extensively in the context of many cancers and much research has centred around the metabolites' anti-proliferative and potentially proapoptotic nature within this setting. 2ME2 is metabolized from its precursor metabolite 2hydroxyestradiol (2OHE2) by the enzyme, COMT. 2ME2 is also readily converted to its less biologically active form 2-methoxyestrone (2ME1) by 17ßHSD2 (Tofovic, 2010). 
It is only within the last decade or so that several studies have outlined the potential beneficial effects of $2 \mathrm{ME} 2$ in the context of pulmonary hypertension. Tofovic et al., have demonstrated that $2 \mathrm{ME} 2$ reversed indices such as RVH, RVSP, pulmonary artery remodeling and increased survival in the monocrotaline and bleomycin models of experimental pulmonary hypertension (Tofovic et al., 2005, Tofovic et al., 2010a). 2ME2 has also been shown to reduce human PASMC and human lung fibroblast proliferation in a concentration dependent manner (Tofovic et al., 2009b) thus demonstrating that 2ME2 has beneficial effects in PASMC remodeling as well as pulmonary fibrosis and associated adventitial remodeling. Indeed, further pre-clinical studies have shown that, in the monocrotalineinduced PH model, combination therapy of 2ME2 and sildenafil significantly reduced pulmonary artery remodeling and inflammatory responses as well as increasing survival (Tofovic et al., 2010b). 2-ethoxyestradiol, a synthetic analogue of 2ME2, also attenuates experimental PH and is 10-times more potent than 2ME2 both in-vitro and in-vivo (Tofovic et al., 2008). The exact mechanism to which 2ME2 exerts its potent anti-proliferative effect are unclear. However, there is evidence to suggest that 2ME2 reduces endothelial cell production of the potent mitogen ET-1 through alterations in mitogen activated protein kinase (MAPK) activity, this reduction in ET-1 was also demonstrated to be ER $\alpha$ and ER $\beta$ independent (Dubey et al., 2001). Further work is required to elucidate the exact mechanism of action of 2ME2 and whether it may well be useful in a clinical setting.

\section{Other potential protective estrogen metabolites}

To date there is limited data demonstrating other beneficial estrogen metabolites; however, some studies have shown that the hydroxy metabolite 2OHE2 can reverse monocrotalineinduced $\mathrm{PH}$ in male rats through a reduction in RVH and pulmonary artery remodeling (Tofovic et al., 2005). 2OHE2 has anti-proliferative effects in rat cardiac fibroblasts and it has been demonstrated that the anti-proliferative effect of 2OHE2 is mediated through conversion to 2ME2 by COMT. Furthermore, 2ME2 and 2OHE2's anti-proliferative effects are independent of ER $\alpha$ and ER $\beta$ (Dubey et al., 2001). 4-hydroxyestradiol (4OHE2) is antiproliferative in male human PASMCs (Mair et al., 2015). Interestingly, 4OHE2 is proproliferative in the breast adenocarcinoma cell line, MCF-7, suggesting possible tissue and cellular specific effects (Seeger et al., 2006). 


\section{Other sex hormones of interest}

Although estrogen and its metabolites have been the focus of research, other sex hormones are biologically active in the pulmonary vasculature. For example, the female steroid hormone progesterone has been shown to be vasodilatory in systemic and pulmonary arteries mediated through an endothelium dependent NO induced induction of cGMP as well as inhibition of voltage and receptor operated calcium channels (Glusa et al., 1997, Li et al., 2001). Furthermore, progesterone is anti-proliferative in aortic smooth muscle cells (Lee et al., 1997); however, whether it is also anti-proliferative in the pulmonary vasculature is unknown. Pre-clinically, progesterone attenuates monocrotaline-induced pulmonary hypertension in rats by reducing RVSP, RVH and vascular remodeling whilst also significantly increasing survival (Tofovic et al., 2009a). However, the effects of progesterone on the pulmonary vasculature in the clinical setting are as yet unknown and an avenue open to future investigation.

The male sex hormone testosterone has also been postulated to be beneficial in the setting of pulmonary hypertension, not only because fewer males are afflicted with the disease but also because it has been shown to be a potent vasodilator in isolated pulmonary arteries of both rats (English et al., 2001) and humans (Smith et al., 2008). However, in human pulmonary arteries, the vasodilatory property of testosterone is much more efficacious in males (Rowell et al., 2009). Indeed, Jones et al., have demonstrated that testosterone is likely to exert this vasodilatory effect via calcium antagonistic effects on voltage gated calcium channels independent of the androgen receptor (Jones et al., 2002). However, in the cardiac setting testosterone has been shown to promote maladaptive RV remodeling and fibrosis suggesting a detrimental effect on overall RV function in the context of increased afterload (Hemnes et al., 2012). This observation is in line with current clinical data where males with PAH have worse clinical outcomes than females (Benza et al., 2010, Humbert et al., 2010). There is little clinical data regarding testosterone treatment in PAH; however, there were no differences observed in plasma testosterone levels between male healthy and PAH patients in a recent study by Ventetuolo and colleagues (Ventetuolo et al., 2016a).

DHEA, the precursor steroid hormone to testosterone, can inhibit hypoxia-induced vasoconstriction of the pulmonary arteries via opening of $\mathrm{Ca}^{2+}$-activated large conductance potassium channels $\left(\mathrm{BK}_{\mathrm{Ca}}\right)$ (Farrukh et al., 1998). In vivo, DHEA also prevents and reverses hypoxia-induced $\mathrm{PH}$ in rats by increasing the expression and functionality of $\mathrm{BK}_{\mathrm{Ca}}$ channels to increase vasodilation of the pulmonary arteries (Bonnet et al., 2003). Indeed, other groups 
have demonstrated the beneficial effects of DHEA on the pulmonary vasculature (Oka et al., 2007) as well as its ability to improve cardiac endpoints such as increasing tricuspid annular plane systolic excursion (TAPSE), RV internal diameter during diastole and cardiac index (CI) ultimately increasing right ventricular function (Alzoubi et al., 2013). Interestingly, DHEA has also been shown to inhibit Src/STAT3 activation and upregulate BMPR-II expression in PASMCs isolated from human PAH patients further outlining its protective effects in the pulmonary vasculature (Paulin et al., 2011). Preliminary clinical studies involving DHEA have been promising, for example in a small clinical trial oral DHEA treatment improved the 6MWD and pulmonary hemodynamics in chronic obstructive pulmonary disease (COPD)-induced PH (Dumas de La Roque et al., 2012). Furthermore, lower plasma DHEA-S levels have been found in male PAH patients, further suggesting a potential protective role for the hormone in the pulmonary vasculature (Ventetuolo et al., 2016a). 


\section{Estrogen receptors and sex-specific differences}

It has become apparent that estrogen receptors impact a multitude of biological functions including inflammatory response, cardiovascular function (El Khoudary, 2017) and bone homeostasis (Bado et al., 2017). The majority of estrogenic activity is via canonical estrogenic signalling. Upon high affinity binding with estrogen these nuclear receptors act as transcription factors regulating gene activity (Lee et al., 2012). Estrogen signaling targets three main classes of estrogen receptors: the nuclear ER $\alpha, E R \beta$ and a transmembrane $G$ protein-coupled estrogen receptor (GPER). All are located in various target organs mediating genomic and non-genomic estrogen signaling. Significantly, in PAH these receptors localise to the PASMCs that may account for estrogen-dependant proliferation and remodelling (Wright et al., 2015b). Structurally ER $\alpha$ and ER $\beta$ both display sequence homology comprising of five distinct domains, two activation domains within the n-terminal and ligandbinding domains regulate the transcriptional activity of ER (Kumar et al., 2011). Due to alternative splicing, several isoforms of each also exist with at least three $\operatorname{ER} \alpha$ and five $\operatorname{ER} \beta$ isoforms discovered to date.

$\mathrm{ER} \alpha$ is highly expressed in female hPASMCs from PAH patients and mediates estrogeninduced proliferation via MAPK and Akt signaling (Wright et al., 2015). High levels of ER $\alpha$ leads to human PASMC proliferation and remodelling, characteristic in PAH, through various canonical signalling pathways (Awad et al., 2016). The second receptor ER $\beta$ may play a more beneficial role in protection against PAH modulating angiogenesis through the production of various angiogenic factors such as vascular endothelial growth factor (VEGF) and NO (de Jesus Perez, 2011) upon estrogen treatment. Interestingly use of an ER $\beta$ agonist induced reversal of PAH symptoms with a prevention of the savour by application of ER $\beta$ antagonists. Therefore, postulations suggest that targeting ER $\beta$ in future therapeutics strategies may lead to the development of PAH treatments (Umar et al., 2011).

The third class and more recently discovered transmembrane GPER, binds estrogen causing rapid non-genomic effects (Wright et al., 2015). In vascular physiology, GPER initiates rapid non-genomic effects via opening of ion channels and activation of various signaling enzymes. Relations between GPER and high blood pressure in aging males and females however the majority of studies to date suggests a beneficial role in the pulmonary vasculature and RV (Lahm et al., 2014). The potential beneficial effects of GPER include anti-fibrotic effects, enhanced cardiac contractibility and most notably the ability to mediate the protective effects of estrogen. Whilst GPER agonists do not exert a proliferative effect on hPASMCs, they have 
been shown to reduce RV overload in PH rats and so GPER's may play a role in the development of experimental PH (Wright et al., 2015, Alencar et al., 2017). 


\section{Serotonin and sex differences in pulmonary hypertension}

5-hydroxytryptamine (5-HT), or "serotonin", was chemically identified by Rapport et al (1948) as one of the major vasoconstricting substances in defibrinated blood, originating from platelets (Rapport et al., 1948). Serotonin was subsequently found to also act as a major neurotransmitter, being involved in a variety of processes carried out by the central nervous system, as well as regulating several functions in the periphery. The biosynthesis pathway converts dietary tryptophan to 5-hydroxytryptophan by the action of the enzyme tryptophan hydroxylase (TPH). This process is the rate-limiting step in the generation of serotonin. Two isoforms of TPH exist; TPH1 is responsible for synthesis of serotonin in the periphery while, TPH2 is expressed abundantly in the brain (Nakamura and Hasegawa, 2007). 5hydroxytryptophan is then decarboxylated by a ubiquitous amino-acid decarboxylase, resulting in the formation of serotonin. The physiological effects of serotonin are then mediated by 14 different 5-HT receptor subtypes. These receptors are divided into 7 distinct classes $\left(5-\mathrm{HT}_{1}-5-\mathrm{HT}_{7}\right)$, mainly on the basis of their structural and functional characteristics. Serotonin is also a substrate for SERT, which actively uptakes serotonin into cells. In the lungs, serotonin is locally released from pulmonary neuroendocrine cells and neuroepithelial cell bodies distributed throughout the airways. Synthesis of serotonin can also occur in PAECs. Furthermore, the lungs play an important role in the removal of serotonin from the circulation, with as much as $95 \%$ being taken up or inactivated. Under normal circumstances, pulmonary tissue is exposed to low levels of serotonin as most serotonin is stored in platelets, thus removing it from the circulation (Wiersma and Roth, 1980, Thomas and Vane, 1967, Gaddum et al., 1953). However, under hypoxic conditions (Johnson and Georgieff, 1989), and during situations involving mechanical strain (Pan et al., 2006), large amounts of serotonin are secreted. In the pulmonary circulation, serotonin promotes PASMC proliferation, vasoconstriction and thrombosis, processes involved in the development of PAH.

An increased incidence of $\mathrm{PH}$ due to use of the anorexigenic drugs aminorex and dexfenfluramine; SERT substrates and indirect serotonergic agonists; stimulated interest in the role of serotonin in PAH, leading to the 'serotonin hypothesis of PAH'. Aminorex increases plasma levels of serotonin by inducing its release from platelets and attenuating its breakdown (Zheng et al., 1997, Fishman, 1999). Dexfenfluramine also increases levels of 
circulating serotonin and interacts with SERT, stimulating the release of serotonin from platelets and inhibit its reuptake (Buczko et al., 1975, Fristrom et al., 1977).

A body of evidence now exists further implicating serotonin and the development of PAH. For instance some cohorts of patients with PAH have elevated plasma levels of serotonin, in addition to a decrease in the levels of serotonin stored in platelets due to platelet pool storage disease (Herve et al., 1995). Furthermore, in PAECs from PAH patients, increased TPH1 expression and serotonin synthesis has been observed and this is thought to contribute to increased PASMC proliferation (Eddahibi et al., 2006). Knockdown of the TPH1 gene also has beneficial effects in animal models of PH (Morecroft et al., 2007, Morecroft et al., 2012). Indeed, synthesis of serotonin has also been associated with the development of the Sugen5416/hypoxic model of PH. Inhibition of the VEGF receptor by Sugen5416 combined with hypoxia generates a preclinical model of PH that recapitulates human PAH more closely than previously characterized models (Gomez-Arroyo et al., 2012). This model is associated with increased expression of TPH1, the rate-limiting enzyme in serotonin synthesis (Ciuclan et al., 2011, Ciuclan et al., 2013).

5-HT receptors, in particular the 5-HT1B receptor and SERT contribute to the actions of serotonin in PH. Serotonin is a potent vasoconstrictor and in human pulmonary arteries mediates its effects via the 5-HT1B receptor (Morecroft et al., 1999), which is also overexpressed in PASMCs from female PAH patients (Wallace et al., 2015) and in the pulmonary circulation of larger experimental models of PH such as pigs (Rondelet et al., 2003). In addition to the role of 5-HT1B receptors in vasoconstriction, they also play a role in mediating cellular proliferation and vascular remodeling. Several cellular studies have demonstrated the mitogenic effects of serotonin on pulmonary artery endothelial, smooth muscle and fibroblast cells. Moreover, in experimental models of PH genetic ablation and pharmacological inhibition of the 5-HT1B receptor attenuate $\mathrm{PH}$ and inhibit pulmonary vascular remodeling (Hood et al., 2017, Keegan et al., 2001). SERT is also critical in mediating the mitogenic effects of serotonin in the pulmonary circulation. Augmented proliferative capabilities of PASMCs from patients with PAH have been associated with increased expression levels of SERT (Eddahibi et al., 2001, Marcos et al., 2004). The enhanced proliferation of these cells to 5-HT or serum can be abolished by SERT inhibitors such as citalopram and fluoxetine (Marcos et al., 2004). In PAH patients, SERT expression is also located mainly in the medial layer of remodeled vessels (Eddahibi et al., 2001). Hypoxia causes increased SERT expression and activity, augmenting mitogenic responses in PASMCs 
(Eddahibi et al., 1999). Serotonin-induced proliferation requires SERT-dependent generation of ROS, activation of the extra-cellular regulated kinase (ERK) pathway and the induction of the transcriptional factor GATA-4. Activation of the Rho kinase pathway by internalised serotonin may also play a role in SERT-mediated proliferation (Lawrie et al., 2005, Liu et al., 2004, Suzuki et al., 2003). Both the serotonin receptors and SERT can also interact in a cooperative fashion to mediate serotonin-induced contraction and proliferation of PASMCs (Morecroft et al., 2005, Lawrie et al., 2005, Liu et al., 2004). Through its actions via SERT and its receptors, serotonin plays a role in the development of $\mathrm{PAH}$, contributing to both vasoconstriction and vascular remodeling. Serotonin can also influence other pathways associated with PH and may act as a "second hit" as exogenous administration of serotonin uncovers a PH phenotype in BMPR-II ${ }^{+/}$mice (Long et al., 2006).

Models of PH have now been characterised that mimic the female susceptibility to PH observed in humans. These models all involve serotonin-dependent mechanisms and include: SERT+ mice, mice overexpressing the calcium-binding protein S100A4/mts1 (that function downstream of serotonin) and mice dosed with the indirect serotonergic agonist dexfenfluramine (Dempsie et al., 2013, Dempsie et al., 2011, White et al., 2011). In each of these models a PH phenotype is only observed in female animals and is estrogen-dependent. For instance, removal of female sex hormones by ovariectomy reverses the $\mathrm{PH}$ phenotype in SERT + mice and the phenotype can be reinstated by replacing estrogen in these animals. Serotonin mechanisms may also be important in regulating estrogen metabolism as SERT overexpression and dexfenfluramine can increase CYP1B1 expression (Dempsie et al., 2013, Johansen et al., 2016). Furthermore, estrogen has been shown to increase the expression of TPH1, SERT, and the 5-HT1B receptor in human PASMCs (Dempsie et al., 2013, White et al., 2011). Indeed, increased 5-HT1B receptor expression in human PASMCs for female PH patients may be the consequence of an estrogen-induced decreases in miRNA-96 expression and contribute to the development of PH in females (Wallace et al., 2015). 


\section{Concluding statement}

Female sex is now recognised as a significant risk factor in the development of PAH. An increasing body of evidence now suggests that estrogen and some of its metabolites may play a role in the pathogenesis of PAH as well as experimental PH (Figure 1). Interactions of estrogen with serotonin and other key pathways may contribute to the development of $\mathrm{PH}$. Furthermore, initial pre-clinical studies suggest that other estrogen metabolites such as 2ME2 and 2OHE2 can reverse experimental PH and may well be useful in the treatment of the human disease.

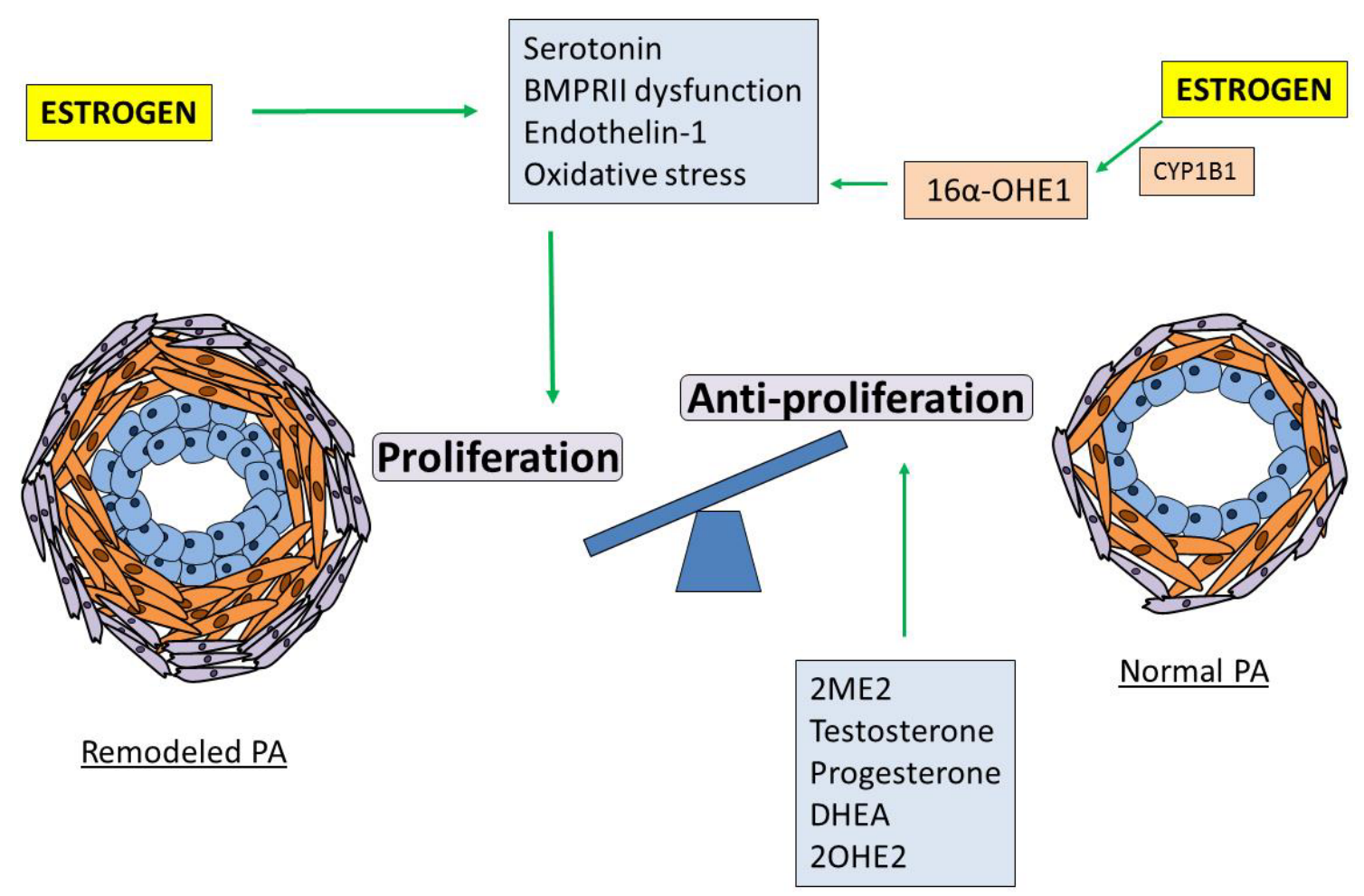

Figure 1. The potential effects of sex hormones and estrogen metabolites on pulmonary artery (PA) remodeling. In remodeled PA's excess proliferation is observed in endothelial cells (blue), smooth muscle cells (orange) and fibroblasts (purple) eventually leading to reduced luminal area. Estrogen itself can increase vascular smooth muscle cell proliferation; however, it has also been postulated to influence the Serotonin and Endothelin-1 pathways as well as reducing BMPRII signaling, all of which are recognized to be pro-proliferative mechanisms. The cytochrome P450 1B1 isoform (CYP1B) enzyme converts estrogen to 16 $\alpha-$ hydroxyestrone $(16 \alpha \mathrm{OHE})$, a metabolite identified to be pro-proliferative by increasing oxidative stress responses. Other sex hormones such as testosterone, dehydroepiandrosterone DHEA and progesterone are known to be anti-proliferative and have been shown to reverse experimental PH. Some estrogen metabolites are also known to reverse experimental PH such as 2-hydroxyestradiol (2OHE2) and 2-methoxyestradiol (2ME2). 


\section{References}

ALENCAR, A. K., MONTES, G. C., MONTAGNOLI, T., SILVA, A. M., MARTINEZ, S. T., FRAGA, A. G., WANG, H., GROBAN, L., SUDO, R. T. \& ZAPATA-SUDO, G. 2017. Activation of GPER ameliorates experimental pulmonary hypertension in male rats. Eur J Pharm Sci, 97, 208217.

ALZOUBI, A., TOBA, M., ABE, K., O'NEILL, K. D., ROCIC, P., FAGAN, K. A., MCMURTRY, I. F. \& OKA, M. 2013. Dehydroepiandrosterone restores right ventricular structure and function in rats with severe pulmonary arterial hypertension. Am J Physiol Heart Circ Physiol, 304, H1708-18.

AUSTIN, E. D., COGAN, J. D., WEST, J. D., HEDGES, L. K., HAMID, R., DAWSON, E. P., WHEELER, L. A., PARL, F. F., LOYD, J. E. \& PHILLIPS, J. A., 3RD 2009. Alterations in oestrogen metabolism: implications for higher penetrance of familial pulmonary arterial hypertension in females. Eur Respir J, 34, 1093-9.

AUSTIN, E. D., HAMID, R., HEMNES, A. R., LOYD, J. E., BLACKWELL, T., YU, C., PHILLIPS III, J. A., GADDIPATI, R., GLADSON, S., GU, E., WEST, J. \& LANE, K. B. 2012. BMPR2 expression is suppressed by signaling through the estrogen receptor. Biol Sex Differ, 3, 6.

AWAD, K. S., WEST, J. D., DE JESUS PEREZ, V. \& MACLEAN, M. 2016. Novel signaling pathways in pulmonary arterial hypertension (2015 Grover Conference Series). Pulm Circ.

BADESCH, D., RASKOB, G., ELLIOTT, C., KRICHMAN, A., FARBER, H., FROST, A., BARST, R., BENZA, R., LIOU, T., TURNER, M., GILES, S., FELDKIRCHER, K., MILLER, D. \& MCGOON, M. 2010.

Pulmonary Arterial Hypertension Baseline Characteristics From the REVEAL Registry. Chest, 137, 376-387.

BADO, I., GUGALA, Z., FUQUA, S. A. W. \& ZHANG, X. H. 2017. Estrogen receptors in breast and bone: from virtue of remodeling to vileness of metastasis. Oncogene, 36, 4527-4537.

BARST, R. J. 2008. Pulmonary hypertension: Past, present and future. Ann Thorac Med.

BENZA, R. L., MILLER, D. P., GOMBERG-MAITLAND, M., FRANTZ, R. P., FOREMAN, A. J., COFFEY, C. S., FROST, A., BARST, R. J., BADESCH, D. B., ELLIOTT, C. G., LIOU, T. G. \& MCGOON, M. D. 2010. Predicting survival in pulmonary arterial hypertension: insights from the Registry to Evaluate Early and Long-Term Pulmonary Arterial Hypertension Disease Management (REVEAL). Circulation, 122, 164-72.

BERETTA, L., CARONNI, M., ORIGGI, L., PONTI, A., SANTANIELLO, A. \& SCORZA, R. 2006. Hormone replacement therapy may prevent the development of isolated pulmonary hypertension in patients with systemic sclerosis and limited cutaneous involvement. Scand J Rheumatol, 35, 468-71.

BONNET, S., DUMAS-DE-LA-ROQUE, E., BEGUERET, H., MARTHAN, R., FAYON, M., DOS SANTOS, P., SAVINEAU, J. P. \& BAULIEU, E. E. 2003. Dehydroepiandrosterone (DHEA) prevents and reverses chronic hypoxic pulmonary hypertension. Proc Natl Acad Sci U S A, 100, 9488-93.

BUCZKO, W., DE GAETANO, G. \& GARATTINI, S. 1975. Effect of fenfluramine on 5-hydroxytryptamine uptake and release by rat blood platelets. Br J Pharmacol, 53, 563-8.

CARROLL-TURPIN, M., HEBERT, V., CHOTIBUT, T., WENSLER, H., KRENTZEL, D., VARNER, K. J., BURN, B. R., CHEN, Y. F., ABREO, F. \& DUGAS, T. R. 2015. 4,4'-Methylenedianiline Alters Serotonergic Transport in a Novel, Sex-Specific Model of Pulmonary Arterial Hypertension in Rats. Toxicol Sci, 147, 235-45.

CHEN, X., AUSTIN, E. D., TALATI, M., FESSEL, J. P., FARBER-EGER, E. H., BRITTAIN, E. L., HEMNES, A. R., LOYD, J. E. \& WEST, J. 2017. Oestrogen inhibition reverses pulmonary arterial hypertension and associated metabolic defects. Eur Respir J, 50.

CHOUDHARY, D., JANSSON, I., STOILOV, I., SARFARAZI, M. \& SCHENKMAN, J. 2004. Metabolism of retinoids and arachidonic acid by human and mouse cytochrome P4501B1. Drug Metabolism and Disposition, 32, 840-847.

CHRISTMAN, B. W., MCPHERSON, C. D., NEWMAN, J. H., KING, G. A., BERNARD, G. R., GROVES, B. M. \& LOYD, J. E. 1992. An imbalance between the excretion of thromboxane and prostacyclin metabolites in pulmonary hypertension. $N$ Engl J Med, 327, 70-5. 
CIUCLAN, L., BONNEAU, O., HUSSEY, M., DUGGAN, N., HOLMES, A. M., GOOD, R., STRINGER, R., JONES, P., MORRELL, N. W., JARAI, G., WALKER, C., WESTWICK, J. \& THOMAS, M. 2011. A novel murine model of severe pulmonary arterial hypertension. Am J Respir Crit Care Med, $184,1171-82$.

CIUCLAN, L., HUSSEY, M. J., BURTON, V., GOOD, R., DUGGAN, N., BEACH, S., JONES, P., FOX, R., CLAY, I., BONNEAU, O., KONSTANTINOVA, I., PEARCE, A., ROWLANDS, D. J., JARAI, G., WESTWICK, J., MACLEAN, M. R. \& THOMAS, M. 2013. Imatinib attenuates hypoxia-induced pulmonary arterial hypertension pathology via reduction in 5-hydroxytryptamine through inhibition of tryptophan hydroxylase 1 expression. Am J Respir Crit Care Med, 187, 78-89.

CLAPP, L. H., FINNEY, P., TURCATO, S., TRAN, S., RUBIN, L. J. \& TINKER, A. 2002. Differential effects of stable prostacyclin analogs on smooth muscle proliferation and cyclic AMP generation in human pulmonary artery. Am J Respir Cell Mol Biol, 26, 194-201.

COGAN, J., AUSTIN, E., HEDGES, L., WOMACK, B., WEST, J., LOYD, J. \& HAMID, R. 2012. Role of BMPR2 alternative splicing in heritable pulmonary arterial hypertension penetrance. Circulation, 126, 1907-16.

CORREALE, M., TOTARO, A., LACEDONIA, D., MONTRONE, D., DI BIASE, M., BARBARO FOSCHINO, M. P. \& BRUNETTI, N. D. 2013. Novelty in treatment of pulmonary fibrosis: pulmonary hypertension drugs and others. Cardiovasc Hematol Agents Med Chem, 11, 169-78.

DE JESUS PEREZ, V. A. 2011. Making sense of the estrogen paradox in pulmonary arterial hypertension. Am J Respir Crit Care Med. United States.

DEAN, A., NILSEN, M., LOUGHLIN, L., SALT, I. P. \& MACLEAN, M. R. 2016. Metformin Reverses Development of Pulmonary Hypertension via Aromatase Inhibition. Hypertension, 68, 44654.

DEMPSIE, Y., MACRITCHIE, N. A., WHITE, K., MORECROFT, I., WRIGHT, A. F., NILSEN, M., LOUGHLIN, L., MAIR, K. M. \& MACLEAN, M. R. 2013. Dexfenfluramine and the oestrogen-metabolizing enzyme CYP1B1 in the development of pulmonary arterial hypertension. Cardiovasc Res, 99, 24-34.

DEMPSIE, Y., NILSEN, M., WHITE, K., MAIR, K. M., LOUGHLIN, L., AMBARTSUMIAN, N., RABINOVITCH, M. \& MACLEAN, M. R. 2011. Development of pulmonary arterial hypertension in mice overexpressing S100A4/Mts1 is specific to females. Respir Res, 12, 159.

DRESDALE, D. T., SCHULTZ, M. \& MICHTOM, R. J. 1951. Primary pulmonary hypertension. I. Clinical and hemodynamic study. Am J Med, 11, 686-705.

DUBEY, R. K., JACKSON, E. K., KELLER, P. J., IMTHURN, B. \& ROSSELLI, M. 2001. Estradiol metabolites inhibit endothelin synthesis by an estrogen receptor-independent mechanism. Hypertension, 37, 640-4.

DUMAS DE LA ROQUE, E., SAVINEAU, J. P., METIVIER, A. C., BILLES, M. A., KRAEMER, J. P., DOUTRELEAU, S., JOUGON, J., MARTHAN, R., MOORE, N., FAYON, M., BAULIEU, E. E. \& DROMER, C. 2012. Dehydroepiandrosterone (DHEA) improves pulmonary hypertension in chronic obstructive pulmonary disease (COPD): a pilot study. Ann Endocrinol (Paris), 73, 205.

DUPUIS, J., STEWART, D. J., CERNACEK, P. \& GOSSELIN, G. 1996. Human pulmonary circulation is an important site for both clearance and production of endothelin-1. Circulation, 94, 1578-84.

EDDAHIBI, S., FABRE, V., BONI, C., MARTRES, M. P., RAFFESTIN, B., HAMON, M. \& ADNOT, S. 1999. Induction of serotonin transporter by hypoxia in pulmonary vascular smooth muscle cells. Relationship with the mitogenic action of serotonin. Circ Res, 84, 329-36.

EDDAHIBI, S., GUIGNABERT, C., BARLIER-MUR, A. M., DEWACHTER, L., FADEL, E., DARTEVELLE, P., HUMBERT, M., SIMONNEAU, G., HANOUN, N., SAURINI, F., HAMON, M. \& ADNOT, S. 2006. Cross talk between endothelial and smooth muscle cells in pulmonary hypertension: critical role for serotonin-induced smooth muscle hyperplasia. Circulation, 113, 1857-64.

EDDAHIBI, S., HUMBERT, M., FADEL, E., RAFFESTIN, B., DARMON, M., CAPRON, F., SIMONNEAU, G., DARTEVELLE, P., HAMON, M. \& ADNOT, S. 2001. Serotonin transporter overexpression is 
responsible for pulmonary artery smooth muscle hyperplasia in primary pulmonary hypertension. J Clin Invest, 108, 1141-50.

EL KHOUDARY, S. R. 2017. Gaps, limitations and new insights on endogenous estrogen and follicle stimulating hormone as related to risk of cardiovascular disease in women traversing the menopause: A narrative review. Maturitas, 104, 44-53.

ENGLISH, K. M., JONES, R. D., JONES, T. H., MORICE, A. H. \& CHANNER, K. S. 2001. Gender differences in the vasomotor effects of different steroid hormones in rat pulmonary and coronary arteries. Horm Metab Res, 33, 645-52.

EVANS, J. D., GIRERD, B., MONTANI, D., WANG, X. J., GALIE, N., AUSTIN, E. D., ELLIOTT, G., ASANO, K., GRUNIG, E., YAN, Y., JING, Z. C., MANES, A., PALAZZINI, M., WHEELER, L. A., NAKAYAMA, I., SATOH, T., EICHSTAEDT, C., HINDERHOFER, K., WOLF, M., ROSENZWEIG, E. B., CHUNG, W. K., SOUBRIER, F., SIMONNEAU, G., SITBON, O., GRAF, S., KAPTOGE, S., DI ANGELANTONIO, E., HUMBERT, M. \& MORRELL, N. W. 2016. BMPR2 mutations and survival in pulmonary arterial hypertension: an individual participant data meta-analysis. Lancet Respir Med, 4, 129-37.

FARRUKH, I. S., PENG, W., ORLINSKA, U. \& HOIDAL, J. R. 1998. Effect of dehydroepiandrosterone on hypoxic pulmonary vasoconstriction: a $\mathrm{Ca}(2+)$-activated $\mathrm{K}(+)$-channel opener. Am J Physiol, 274, L186-95.

FISHMAN, A. P. 1999. Aminorex to fen/phen: an epidemic foretold. Circulation, 99, 156-61.

FODERARO, A. \& VENTETUOLO, C. E. 2016. Pulmonary Arterial Hypertension and the Sex Hormone Paradox. Curr Hypertens Rep, 18, 84.

FORBES, J. F., CUZICK, J., BUZDAR, A., HOWELL, A., TOBIAS, J. S. \& BAUM, M. 2008. Effect of anastrozole and tamoxifen as adjuvant treatment for early-stage breast cancer: 100-month analysis of the ATAC trial. Lancet Oncol, 9, 45-53.

FRISTROM, S., AIRAKSINEN, M. M. \& HALMEKOSKI, J. 1977. Release of platelet 5-hydroxytryptamine by some anorexic and other sympathomimetics and their acetyl derivatives. Acta Pharmacol Toxicol (Copenh), 41, 218-24.

GABLER, N. B., FRENCH, B., STROM, B. L., LIU, Z., PALEVSKY, H. I., TAICHMAN, D. B., KAWUT, S. M. \& HALPERN, S. D. 2012. Race and sex differences in response to endothelin receptor antagonists for pulmonary arterial hypertension. Chest, 141, 20-6.

GADDUM, J. H., HEBB, C. O., SILVER, A. \& SWAN, A. A. 1953. 5-Hydroxytryptamine; pharmacological action and destruction in perfused lungs. Q J Exp Physiol Cogn Med Sci, 38, 255-62.

GALIE, N., HOEPER, M. M., HUMBERT, M., TORBICKI, A., VACHIERY, J. L., BARBERA, J. A., BEGHETTI, M., CORRIS, P., GAINE, S., GIBBS, J. S., GOMEZ-SANCHEZ, M. A., JONDEAU, G., KLEPETKO, W., OPITZ, C., PEACOCK, A., RUBIN, L., ZELLWEGER, M., SIMONNEAU, G. \& GUIDELINES, E. S. C. C. F. P. 2009. Guidelines for the diagnosis and treatment of pulmonary hypertension: the Task Force for the Diagnosis and Treatment of Pulmonary Hypertension of the European Society of Cardiology (ESC) and the European Respiratory Society (ERS), endorsed by the International Society of Heart and Lung Transplantation (ISHLT). Eur Heart J, 30, 2493-537.

GAO, X. F., ZHANG, J. J., JIANG, X. M., GE, Z., WANG, Z. M., LI, B., MAO, W. X. \& CHEN, S. L. 2017. Targeted drugs for pulmonary arterial hypertension: a network meta-analysis of 32 randomized clinical trials. Patient Prefer Adherence, 11, 871-885.

GARCIA DE VINUESA, A., ABDELILAH-SEYFRIED, S., KNAUS, P., ZWIJSEN, A. \& BAILLY, S. 2016. BMP signaling in vascular biology and dysfunction. Cytokine Growth Factor Rev, 27, 65-79.

GIAID, A., YANAGISAWA, M., LANGLEBEN, D., MICHEL, R. P., LEVY, R., SHENNIB, H., KIMURA, S., MASAKI, T., DUGUID, W. P. \& STEWART, D. J. 1993. Expression of endothelin-1 in the lungs of patients with pulmonary hypertension. N Engl J Med, 328, 1732-9.

GLUSA, E., GRASER, T., WAGNER, S. \& OETTEL, M. 1997. Mechanisms of relaxation of rat aorta in response to progesterone and synthetic progestins. Maturitas, 28, 181-91.

GOMEZ-ARROYO, J., SALEEM, S. J., MIZUNO, S., SYED, A. A., BOGAARD, H. J., ABBATE, A., TARASEVICIENE-STEWART, L., SUNG, Y., KRASKAUSKAS, D., FARKAS, D., CONRAD, D. H., NICOLLS, M. R. \& VOELKEL, N. F. 2012. A brief overview of mouse models of pulmonary 
arterial hypertension: problems and prospects. Am J Physiol Lung Cell Mol Physiol, 302, L977-91.

HARADA, N., HONDA, S. I. \& HATANO, O. 1999. Aromatase inhibitors and enzyme stability. Endocr Relat Cancer, 6, 211-8.

HEMNES, A. R., KIELY, D. G., COCKRILL, B. A., SAFDAR, Z., WILSON, V. J., AL HAZMI, M., PRESTON, I. R., MACLEAN, M. R. \& LAHM, T. 2015. Statement on pregnancy in pulmonary hypertension from the Pulmonary Vascular Research Institute. Pulm Circ, 5, 435-65.

HEMNES, A. R., MAYNARD, K. B., CHAMPION, H. C., GLEAVES, L., PENNER, N., WEST, J. \& NEWMAN, J. H. 2012. Testosterone negatively regulates right ventricular load stress responses in mice. Pulm Circ, 2, 352-8.

HERVE, P., LAUNAY, J. M., SCROBOHACI, M. L., BRENOT, F., SIMONNEAU, G., PETITPRETZ, P., POUBEAU, P., CERRINA, J., DUROUX, P. \& DROUET, L. 1995. Increased plasma serotonin in primary pulmonary hypertension. Am J Med, 99, 249-54.

HIRATA, Y., EMORI, T., EGUCHI, S., KANNO, K., IMAI, T., OHTA, K. \& MARUMO, F. 1993. Endothelin receptor subtype $B$ mediates synthesis of nitric oxide by cultured bovine endothelial cells. J Clin Invest, 91, 1367-73.

HOEPER, M. M. \& GIBBS, J. S. R. 2014. The changing landscape of pulmonary arterial hypertension and implications for patient care.

HOOD, K. Y., MAIR, K. M., HARVEY, A. P., MONTEZANO, A. C., TOUYZ, R. M. \& MACLEAN, M. R. 2017. Serotonin Signaling Through the 5-HT1B Receptor and NADPH Oxidase 1 in Pulmonary Arterial Hypertension. Arterioscler Thromb Vasc Biol, 37, 1361-1370.

HOOD, K. Y., MONTEZANO, A. C., HARVEY, A. P., NILSEN, M., MACLEAN, M. R. \& TOUYZ, R. M. 2016. Nicotinamide Adenine Dinucleotide Phosphate Oxidase-Mediated Redox Signaling and Vascular Remodeling by 16alpha-Hydroxyestrone in Human Pulmonary Artery Cells: Implications in Pulmonary Arterial Hypertension. Hypertension.

HUMBERT, M., MONTANI, D., PERROS, F., DORFMÜLLER, P., ADNOT, S. \& EDDAHIBI, S. 2008. Endothelial cell dysfunction and cross talk between endothelium and smooth muscle cells in pulmonary arterial hypertension. Vascul Pharmacol, 49, 113-8.

HUMBERT, M., SITBON, O., YAICI, A., MONTANI, D., O'CALLAGHAN, D. S., JAIS, X., PARENT, F., SAVALE, L., NATALI, D., GUNTHER, S., CHAOUAT, A., CHABOT, F., CORDIER, J. F., HABIB, G., GRESSIN, V., JING, Z. C., SOUZA, R. \& SIMONNEAU, G. 2010. Survival in incident and prevalent cohorts of patients with pulmonary arterial hypertension. Eur Respir J, 36, 549-55.

JACOBS, W., VAN DE VEERDONK, M. C., TRIP, P., DE MAN, F., HEYMANS, M. W., MARCUS, J. T., KAWUT, S. M., BOGAARD, H. J., BOONSTRA, A. \& VONK NOORDEGRAAF, A. 2014. The right ventricle explains sex differences in survival in idiopathic pulmonary arterial hypertension. Chest, 145, 1230-1236.

JOHANSEN, A. K., DEAN, A., MORECROFT, I., HOOD, K., NILSEN, M., LOUGHLIN, L., ANAGNOSTOPOULOU, A., TOUYZ, R. M., WHITE, K. \& MACLEAN, M. R. 2016. The serotonin transporter promotes a pathological estrogen metabolic pathway in pulmonary hypertension via cytochrome P450 1B1. Pulm Circ, 6, 82-92.

JOHNSON, D. E. \& GEORGIEFF, M. K. 1989. Pulmonary neuroendocrine cells. Their secretory products and their potential roles in health and chronic lung disease in infancy. Am Rev Respir Dis, 140, 1807-12.

JONES, R. D., ENGLISH, K. M., PUGH, P. J., MORICE, A. H., JONES, T. H. \& CHANNER, K. S. 2002. Pulmonary vasodilatory action of testosterone: evidence of a calcium antagonistic action. $J$ Cardiovasc Pharmacol, 39, 814-23.

KAWUT, S. M., ARCHER-CHICKO, C. L., DIMICHELE, A., FRITZ, J. S., KLINGER, J. R., KY, B., PALEVSKY, H. I., PALMISCIANO, A. J., PATEL, M., PINDER, D., PROPERT, K. J., SMITH, K. A., STANCZYK, F., TRACY, R., VAIDYA, A., WHITTENHALL, M. E. \& VENTETUOLO, C. E. 2016. Anastrozole in Pulmonary Arterial Hypertension (AIPH): A Randomized, Double-Blind Placebo-Controlled Trial. Am J Respir Crit Care Med. 
KEEGAN, A., MORECROFT, I., SMILLIE, D., HICKS, M. N. \& MACLEAN, M. R. 2001. Contribution of the $5-\mathrm{HT}(1 \mathrm{~B})$ receptor to hypoxia-induced pulmonary hypertension: converging evidence using 5-HT(1B)-receptor knockout mice and the 5-HT(1B/1D)-receptor antagonist GR127935. Circ Res, 89, 1231-9.

KNOWLTON, A. A. 2012. Estrogen and cardiovascular disease: aging and estrogen loss at the heart of the matter? Future Cardiol, 8, 9-12.

KUMAR, R., ZAKHAROV, M. N., KHAN, S. H., MIKI, R., JANG, H., TORALDO, G., SINGH, R., BHASIN, S. \& JASUJA, R. 2011. The Dynamic Structure of the Estrogen Receptor. J Amino Acids, 2011.

LAHM, T., ALBRECHT, M., FISHER, A., SELEJ, M., PATEL, N., BROWN, J., JUSTICE, M., BROWN, M., VAN DEMARK, M., TRULOCK, K., DIEUDONNE, D., REDDY, J., PRESSON, R. \& PETRACHE, I. 2012. 17 beta-Estradiol Attenuates Hypoxic Pulmonary Hypertension via Estrogen Receptor-mediated Effects. American Journal of Respiratory and Critical Care Medicine, 185, 965-980.

LAHM, T., TUDER, R. \& PETRACHE, I. 2014. Progress in solving the sex hormone paradox in pulmonary hypertension. American Journal of Physiology-Lung Cellular and Molecular Physiology, 307, L7-L26.

LAU, E. M. T., GIANNOULATOU, E., CELERMAJER, D. S. \& HUMBERT, M. 2017. Epidemiology and treatment of pulmonary arterial hypertension. Nat Rev Cardiol, 14, 603-614.

LAWRIE, A., SPIEKERKOETTER, E., MARTINEZ, E. C., AMBARTSUMIAN, N., SHEWARD, W. J., MACLEAN, M. R., HARMAR, A. J., SCHMIDT, A. M., LUKANIDIN, E. \& RABINOVITCH, M. 2005. Interdependent serotonin transporter and receptor pathways regulate S100A4/Mts1, a gene associated with pulmonary vascular disease. Circ Res, 97, 227-35.

LEE, H. R., KIM, T. H. \& CHOI, K. C. 2012. Functions and physiological roles of two types of estrogen receptors, ER $\alpha$ and ER $\beta$, identified by estrogen receptor knockout mouse. Lab Anim Res, 28, 71-6.

LEE, W. S., HARDER, J. A., YOSHIZUMI, M., LEE, M. E. \& HABER, E. 1997. Progesterone inhibits arterial smooth muscle cell proliferation. Nat Med, 3, 1005-8.

LI, H. F., ZHENG, T. Z., LI, W., QU, S. Y. \& ZHANG, C. L. 2001. Effect of progesterone on the contractile response of isolated pulmonary artery in rabbits. Can J Physiol Pharmacol, 79, 545-50.

LIAN, T. Y., JIANG, X. \& JING, Z. C. 2017. Riociguat: a soluble guanylate cyclase stimulator for the treatment of pulmonary hypertension. Drug Des Devel Ther, 11, 1195-1207.

LIU, A., SCHREIER, D., TIAN, L., EICKHOFF, J. C., WANG, Z., HACKER, T. A. \& CHESLER, N. C. 2014. Direct and indirect protection of right ventricular function by estrogen in an experimental model of pulmonary arterial hypertension. Am J Physiol Heart Circ Physiol, 307, H273-83.

LIU, Y., SUZUKI, Y. J., DAY, R. M. \& FANBURG, B. L. 2004. Rho kinase-induced nuclear translocation of ERK1/ERK2 in smooth muscle cell mitogenesis caused by serotonin. Circ Res, 95, 579-86.

LONG, L., MACLEAN, M. R., JEFFERY, T. K., MORECROFT, I., YANG, X., RUDARAKANCHANA, N., SOUTHWOOD, M., JAMES, V., TREMBATH, R. C. \& MORRELL, N. W. 2006. Serotonin increases susceptibility to pulmonary hypertension in BMPR2-deficient mice. Circ Res, 98, 818-27.

MACHADO, R. D., ALDRED, M. A., JAMES, V., HARRISON, R. E., PATEL, B., SCHWALBE, E. C., GRUENIG, E., JANSSEN, B., KOEHLER, R., SEEGER, W., EICKELBERG, O., OLSCHEWSKI, H., ELLIOTT, C. G., GLISSMEYER, E., CARLQUIST, J., KIM, M., TORBICKI, A., FIJALKOWSKA, A., SZEWCZYK, G., PARMA, J., ABRAMOWICZ, M. J., GALIE, N., MORISAKI, H., KYOTANI, S., NAKANISHI, N., MORISAKI, T., HUMBERT, M., SIMONNEAU, G., SITBON, O., SOUBRIER, F., COULET, F., MORRELL, N. W. \& TREMBATH, R. C. 2006. Mutations of the TGF-beta type II receptor BMPR2 in pulmonary arterial hypertension. Hum Mutat, 27, 121-32.

MACHADO, R. D., EICKELBERG, O., ELLIOTT, C. G., GERACI, M. W., HANAOKA, M., LOYD, J. E., NEWMAN, J. H., PHILLIPS, J. A., 3RD, SOUBRIER, F., TREMBATH, R. C. \& CHUNG, W. K. 2009. Genetics and genomics of pulmonary arterial hypertension. J Am Coll Cardiol, 54, S32-42.

MACLEAN, M., JOHNSTON, E., MCCULLOCH, K., POOLEY, L., HOUSLAY, M. \& SWEENEY, G. 1997. Phosphodiesterase isoforms in the pulmonary arterial circulation of the rat: Changes in pulmonary hypertension. Journal of Pharmacology and Experimental Therapeutics, 283, 619624. 
MAIR, K. M., JOHANSEN, A. K., WRIGHT, A. F., WALLACE, E. \& MACLEAN, M. R. 2014a. Pulmonary arterial hypertension: basis of sex differences in incidence and treatment response. $B r \mathrm{~J}$ Pharmacol, 171, 567-79.

MAIR, K. M., WRIGHT, A. F., DUGGAN, N., ROWLANDS, D. J., HUSSEY, M. J., ROBERTS, S., FULLERTON, J., NILSEN, M., LOUGHLIN, L., THOMAS, M. \& MACLEAN, M. R. 2014b. Sex-dependent influence of endogenous estrogen in pulmonary hypertension. Am J Respir Crit Care Med, 190, 456-67.

MAIR, K. M., YANG, X. D., LONG, L., WHITE, K., WALLACE, E., EWART, M. A., DOCHERTY, C. K., MORRELL, N. W. \& MACLEAN, M. R. 2015. Sex affects bone morphogenetic protein type II receptor signaling in pulmonary artery smooth muscle cells. Am J Respir Crit Care Med, 191, 693-703.

MARCOS, E., FADEL, E., SANCHEZ, O., HUMBERT, M., DARTEVELLE, P., SIMONNEAU, G., HAMON, M., ADNOT, S. \& EDDAHIBI, S. 2004. Serotonin-induced smooth muscle hyperplasia in various forms of human pulmonary hypertension. Circ Res, 94, 1263-70.

MASI, A. 1976. PULMONARY-HYPERTENSION AND ORAL-CONTRACEPTIVE USAGE. Chest, 69, 451 453.

MATHAI, S. C., HASSOUN, P. M., PUHAN, M. A., ZHOU, Y. \& WISE, R. A. 2015. Sex Differences in Response to Tadalafil in Pulmonary Arterial Hypertension. Chest.

MCCULLOCH, K. M., DOCHERTY, C. C., MORECROFT, I. \& MACLEAN, M. R. 1996. EndothelinB receptor-mediated contraction in human pulmonary resistance arteries. Br J Pharmacol, 119, 1125-30.

MEDHORA, M., CHEN, Y., GRUENLOH, S., HARLAND, D., BODIGA, S., ZIELONKA, J., GEBREMEDHIN, D., GAO, Y., FALCK, J. R., ANJAIAH, S. \& JACOBS, E. R. 2008. 20-HETE increases superoxide production and activates NAPDH oxidase in pulmonary artery endothelial cells. Am J Physiol Lung Cell Mol Physiol, 294, L902-11.

MENDELSOHN, M. E. \& KARAS, R. H. 1999. The protective effects of estrogen on the cardiovascular system. N Engl J Med, 340, 1801-11.

MONTANI, D., CHAUMAIS, M. C., GUIGNABERT, C., GÜNTHER, S., GIRERD, B., JAÏS, X., ALGALARRONDO, V., PRICE, L. C., SAVALE, L., SITBON, O., SIMONNEAU, G. \& HUMBERT, M. 2014. Targeted therapies in pulmonary arterial hypertension. Pharmacol Ther, 141, 172-91.

MONTANI, D., GÜNTHER, S., DORFMÜLLER, P., PERROS, F., GIRERD, B., GARCIA, G., JAÏS, X., SAVALE, L., ARTAUD-MACARI, E., PRICE, L. C., HUMBERT, M., SIMONNEAU, G. \& SITBON, O. 2013. Pulmonary arterial hypertension. Orphanet J Rare Dis.

MORECROFT, I., DEMPSIE, Y., BADER, M., WALTHER, D. J., KOTNIK, K., LOUGHLIN, L., NILSEN, M. \& MACLEAN, M. R. 2007. Effect of tryptophan hydroxylase 1 deficiency on the development of hypoxia-induced pulmonary hypertension. Hypertension, 49, 232-6.

MORECROFT, I., HEELEY, R. P., PRENTICE, H. M., KIRK, A. \& MACLEAN, M. R. 1999. 5hydroxytryptamine receptors mediating contraction in human small muscular pulmonary arteries: importance of the 5-HT1B receptor. Br J Pharmacol, 128, 730-4.

MORECROFT, I., LOUGHLIN, L., NILSEN, M., COLSTON, J., DEMPSIE, Y., SHEWARD, J., HARMAR, A. \& MACLEAN, M. R. 2005. Functional interactions between 5-hydroxytryptamine receptors and the serotonin transporter in pulmonary arteries. J Pharmacol Exp Ther, 313, 539-48.

MORECROFT, I., WHITE, K., CARUSO, P., NILSEN, M., LOUGHLIN, L., ALBA, R., REYNOLDS, P. N., DANILOV, S. M., BAKER, A. H. \& MACLEAN, M. R. 2012. Gene therapy by targeted adenovirus-mediated knockdown of pulmonary endothelial Tph1 attenuates hypoxiainduced pulmonary hypertension. Mol Ther, 20, 1516-28.

MORRELL, N. W., ADNOT, S., ARCHER, S. L., DUPUIS, J., JONES, P. L., MACLEAN, M. R., MCMURTRY, I. F., STENMARK, K. R., THISTLETHWAITE, P. A., WEISSMANN, N., YUAN, J. X. \& WEIR, E. K. 2009. Cellular and molecular basis of pulmonary arterial hypertension. J Am Coll Cardiol, 54, S20-31.

MUECK, A. O., SEEGER, H. \& LIPPERT, T. H. 2002. Estradiol metabolism and malignant disease. Maturitas, 43, 1-10. 
NAKAMURA, K. \& HASEGAWA, H. 2007. Developmental role of tryptophan hydroxylase in the nervous system. Mol Neurobiol, 35, 45-54.

NEBERT, D. W. \& DALTON, T. P. 2006. The role of cytochrome P450 enzymes in endogenous signalling pathways and environmental carcinogenesis. Nat Rev Cancer, 6, 947-60.

NEWMAN, J. H., TREMBATH, R. C., MORSE, J. A., GRUNIG, E., LOYD, J. E., ADNOT, S., COCCOLO, F., VENTURA, C., PHILLIPS, J. A., 3RD, KNOWLES, J. A., JANSSEN, B., EICKELBERG, O., EDDAHIBI, S., HERVE, P., NICHOLS, W. C. \& ELLIOTT, G. 2004. Genetic basis of pulmonary arterial hypertension: current understanding and future directions. J Am Coll Cardiol, 43, 33s-39s.

OHTA, A., NAGAI, M., NISHINA, M., TOMIMITSU, H. \& KOHSAKA, H. 2013. Age at onset and gender distribution of systemic lupus erythematosus, polymyositis/dermatomyositis, and systemic sclerosis in Japan. Mod Rheumatol, 23, 759-64.

OKA, M., KAROOR, V., HOMMA, N., NAGAOKA, T., SAKAO, E., GOLEMBESKI, S. M., LIMBIRD, J., IMAMURA, M., GEBB, S. A., FAGAN, K. A. \& MCMURTRY, I. F. 2007. Dehydroepiandrosterone upregulates soluble guanylate cyclase and inhibits hypoxic pulmonary hypertension. Cardiovasc Res, 74, 377-87.

PAN, J., COPLAND, I., POST, M., YEGER, H. \& CUTZ, E. 2006. Mechanical stretch-induced serotonin release from pulmonary neuroendocrine cells: implications for lung development. Am J Physiol Lung Cell Mol Physiol, 290, L185-93.

PAULIN, R., MELOCHE, J., JACOB, M. H., BISSERIER, M., COURBOULIN, A. \& BONNET, S. 2011. Dehydroepiandrosterone inhibits the Src/STAT3 constitutive activation in pulmonary arterial hypertension. Am J Physiol Heart Circ Physiol, 301, H1798-809.

RABINOVITCH, M. 2012. Molecular pathogenesis of pulmonary arterial hypertension. J Clin Invest, 122, 4306-13.

RAPPORT, M. M., GREEN, A. A. \& PAGE, I. H. 1948. Crystalline Serotonin. Science, 108, 329-30.

RASHID, J., PATEL, B., NOZIK-GRAYCK, E., MCMURTRY, I. F., STENMARK, K. R. \& AHSAN, F. 2017. Inhaled sildenafil as an alternative to oral sildenafil in the treatment of pulmonary arterial hypertension (PAH). J Control Release, 250, 96-106.

ROBERTS, K., FALLON, M., KROWKA, M., BROWN, R., TROTTER, J., PETER, I., TIGHIOUART, H., KNOWLES, J., RABINOWITZ, D., BENZA, R., BADESCH, D., TAICHMAN, D., HORN, E., ZACKS, S., KAPLOWITZ, N., KAWUT, S., DIS, P. V. C. L. \& DIS, P. V. C. L. 2009. Genetic Risk Factors for Portopulmonary Hypertension in Patients with Advanced Liver Disease. American Journal of Respiratory and Critical Care Medicine, 179, 835-842.

RONDELET, B., VAN BENEDEN, R., KERBAUL, F., MOTTE, S., FESLER, P., MCENTEE, K., BRIMIOULLE, S., KETELSLEGERS, J. M. \& NAEIJE, R. 2003. Expression of the serotonin $1 \mathrm{~b}$ receptor in experimental pulmonary hypertension. Eur Respir J, 22, 408-12.

ROWELL, K. O., HALL, J., PUGH, P. J., JONES, T. H., CHANNER, K. S. \& JONES, R. D. 2009. Testosterone acts as an efficacious vasodilator in isolated human pulmonary arteries and veins: evidence for a biphasic effect at physiological and supra-physiological concentrations. J Endocrinol Invest, 32, 718-23.

SEEGER, H., WALLWIENER, D., KRAEMER, E. \& MUECK, A. O. 2006. Comparison of possible carcinogenic estradiol metabolites: effects on proliferation, apoptosis and metastasis of human breast cancer cells. Maturitas, 54, 72-7.

SEO, B., OEMAR, B. S., SIEBENMANN, R., VON SEGESSER, L. \& LUSCHER, T. F. 1994. Both ETA and ETB receptors mediate contraction to endothelin-1 in human blood vessels. Circulation, 89 , $1203-8$.

SHAPIRO, S., POLLOCK, D., GILLIES, H., HENIG, N., ALLARD, M., BLAIR, C., ANGLEN, C. \& KOHAN, D. 2012. Frequency of Edema in Patients With Pulmonary Arterial Hypertension Receiving Ambrisentan. American Journal of Cardiology, 110, 1373-1377.

SHARMA, K. 2015. Selexipag for the Treatment of Pulmonary Arterial Hypertension. Expert Rev Respir Med.

SHICHIRI, M., KATO, H., MARUMO, F. \& HIRATA, Y. 1997. Endothelin-1 as an autocrine/paracrine apoptosis survival factor for endothelial cells. Hypertension, 30, 1198-203. 
SIMONNEAU, G., GATZOULIS, M. A., ADATIA, I., CELERMAJER, D., DENTON, C., GHOFRANI, A., GOMEZ SANCHEZ, M. A., KRISHNA KUMAR, R., LANDZBERG, M., MACHADO, R. F., OLSCHEWSKI, H., ROBBINS, I. M. \& SOUZA, R. 2013. Updated clinical classification of pulmonary hypertension. J Am Coll Cardiol, 62, D34-41.

SIMPSON, E. R. 2003. Sources of estrogen and their importance. J Steroid Biochem Mol Biol, 86, 22530.

SMITH, A. M., BENNETT, R. T., JONES, T. H., COWEN, M. E., CHANNER, K. S. \& JONES, R. D. 2008. Characterization of the vasodilatory action of testosterone in the human pulmonary circulation. Vasc Health Risk Manag, 4, 1459-66.

STASCH, J. P. \& EVGENOV, O. V. 2013. Soluble guanylate cyclase stimulators in pulmonary hypertension. Handb Exp Pharmacol, 218, 279-313.

STEWART, D. J., LEVY, R. D., CERNACEK, P. \& LANGLEBEN, D. 1991. Increased plasma endothelin-1 in pulmonary hypertension: marker or mediator of disease? Ann Intern Med, 114, 464-9.

SUZUKI, Y. J., DAY, R. M., TAN, C. C., SANDVEN, T. H., LIANG, Q., MOLKENTIN, J. D. \& FANBURG, B. L. 2003. Activation of GATA-4 by serotonin in pulmonary artery smooth muscle cells. J Biol Chem, 278, 17525-31.

TEREK, D., KAYIKCIOGLU, M., KULTURSAY, H., ERGENOGLU, M., YALAZ, M., MUSAYEV, O., MOGULKOC, N., GUNUSEN, I., AKISU, M. \& KULTURSAY, N. 2013. Pulmonary arterial hypertension and pregnancy. $J$ Res Med Sci.

THOMAS, D. P. \& VANE, J. R. 1967. 5-hydroxytryptamine in the circulation of the dog. Nature, 216, 335-8.

TOFOVIC, P. S., ZHANG, X. \& PETRUSEVSKA, G. 2009a. Progesterone inhibits vascular remodeling and attenuates monocrotaline-induced pulmonary hypertension in estrogen-deficient rats. Prilozi, 30, 25-44.

TOFOVIC, S. P. 2010. Estrogens and development of pulmonary hypertension: interaction of estradiol metabolism and pulmonary vascular disease. J Cardiovasc Pharmacol, 56, 696-708.

TOFOVIC, S. P. \& JACKSON, E. K. 2013. Complexities of oestradiol pharmacology in pulmonary arterial hypertension. Eur Respir J, 41, 1465-6.

TOFOVIC, S. P., JONES, T. \& PETRUSEVSKA, G. 2010a. Dose-dependent therapeutic effects of 2Methoxyestradiol on Monocrotaline-Induced pulmonary hypertension and vascular remodelling. Prilozi, 31, 279-95.

TOFOVIC, S. P., JONES, T. J., BILAN, V. P., JACKSON, E. K. \& PETRUSEVSKA, G. 2010b. Synergistic therapeutic effects of 2-methoxyestradiol with either sildenafil or bosentan on amelioration of monocrotaline-induced pulmonary hypertension and vascular remodeling. J Cardiovasc Pharmacol, 56, 475-83.

TOFOVIC, S. P., SALAH, E. M., MADY, H. H., JACKSON, E. K. \& MELHEM, M. F. 2005. Estradiol metabolites attenuate monocrotaline-induced pulmonary hypertension in rats. $J$ Cardiovasc Pharmacol, 46, 430-7.

TOFOVIC, S. P., ZHANG, X., JACKSON, E. K., ZHU, H. \& PETRUSEVSKA, G. 2009b. 2-methoxyestradiol attenuates bleomycin-induced pulmonary hypertension and fibrosis in estrogen-deficient rats. Vascul Pharmacol, 51, 190-7.

TOFOVIC, S. P., ZHANG, X., ZHU, H., JACKSON, E. K., RAFIKOVA, O. \& PETRUSEVSKA, G. 2008. 2Ethoxyestradiol is antimitogenic and attenuates monocrotaline-induced pulmonary hypertension and vascular remodeling. Vascul Pharmacol, 48, 174-83.

TSUCHIYA, Y., NAKAJIMA, M. \& YOKOI, T. 2005. Cytochrome P450-mediated metabolism of estrogens and its regulation in human. Cancer Lett, 227, 115-24.

TUDER, R. M., ARCHER, S. L., DORFMÜLLER, P., ERZURUM, S. C., GUIGNABERT, C., MICHELAKIS, E., RABINOVITCH, M., SCHERMULY, R., STENMARK, K. R. \& MORRELL, N. W. 2013. Relevant issues in the pathology and pathobiology of pulmonary hypertension. J Am Coll Cardiol, 62, D4-12. 
TUDER, R. M., COOL, C. D., GERACI, M. W., WANG, J., ABMAN, S. H., WRIGHT, L., BADESCH, D. \& VOELKEL, N. F. 1999. Prostacyclin synthase expression is decreased in lungs from patients with severe pulmonary hypertension. Am J Respir Crit Care Med, 159, 1925-32.

UMAR, S., IORGA, A., MATORI, H., NADADUR, R. D., LI, J., MALTESE, F., VAN DER LAARSE, A. \& EGHBALI, M. 2011. Estrogen Rescues Preexisting Severe Pulmonary Hypertension in Rats. Am J Respir Crit Care Med.

UMAR, S., RABINOVITCH, M. \& EGHBALI, M. 2012. Estrogen paradox in pulmonary hypertension: current controversies and future perspectives. Am J Respir Crit Care Med, 186, 125-31.

VAN DER BRUGGEN, C. E., HAPPE, C. M., DORFMULLER, P., TRIP, P., SPRUIJT, O. A., ROL, N., HOEVENAARS, F. P., HOUWELING, A. C., GIRERD, B., MARCUS, J. T., MERCIER, O., HUMBERT, M., HANDOKO, M. L., VAN DER VELDEN, J., VONK NOORDEGRAAF, A., BOGAARD, H. J., GOUMANS, M. J. \& DE MAN, F. S. 2016. Bone Morphogenetic Protein Receptor Type 2 Mutation in Pulmonary Arterial Hypertension: A View on the Right Ventricle. Circulation, 133, 1747-60.

VENTETUOLO, C. E., BAIRD, G. L., BARR, R. G., BLUEMKE, D. A., FRITZ, J. S., HILL, N. S., KLINGER, J. R., LIMA, J. A., OUYANG, P., PALEVSKY, H. I., PALMISCIANO, A. J., KRISHNAN, I., PINDER, D., PRESTON, I. R., ROBERTS, K. E. \& KAWUT, S. M. 2016a. Higher Estradiol and Lower Dehydroepiandrosterone-Sulfate Levels Are Associated with Pulmonary Arterial Hypertension in Men. Am J Respir Crit Care Med, 193, 1168-75.

VENTETUOLO, C. E., MITRA, N., WAN, F., MANICHAIKUL, A., BARR, R. G., JOHNSON, C., BLUEMKE, D. A., LIMA, J. A., TANDRI, H., OUYANG, P. \& KAWUT, S. M. 2016b. Oestradiol metabolism and androgen receptor genotypes are associated with right ventricular function. Eur Respir J, 47, 553-63.

VENTETUOLO, C. E., PRAESTGAARD, A., PALEVSKY, H. I., KLINGER, J. R., HALPERN, S. D. \& KAWUT, S. M. 2014. Sex and haemodynamics in pulmonary arterial hypertension. Eur Respir J, 43, 52330.

WALLACE, E., MORRELL, N. W., YANG, X. D., LONG, L., STEVENS, H., NILSEN, M., LOUGHLIN, L., MAIR, K. M., BAKER, A. H. \& MACLEAN, M. R. 2015. A Sex-Specific MicroRNA-96/5-

Hydroxytryptamine 1B Axis Influences Development of Pulmonary Hypertension. Am J Respir Crit Care Med, 191, 1432-42.

WHITE, K., DEMPSIE, Y., NILSEN, M., WRIGHT, A. F., LOUGHLIN, L. \& MACLEAN, M. R. 2011. The serotonin transporter, gender, and 17beta oestradiol in the development of pulmonary arterial hypertension. Cardiovasc Res, 90, 373-82.

WHITE, K., JOHANSEN, A., NILSEN, M., CIUCLAN, L., WALLACE, E., PATON, L., CAMPBELL, A., MORECROFT, I., LOUGHLIN, L., MCCLURE, J., THOMAS, M., MAIR, K. \& MACLEAN, M. 2012. Activity of the Estrogen-Metabolizing Enzyme Cytochrome P450 1B1 Influences the Development of Pulmonary Arterial Hypertension. Circulation, 126, 1087-U202.

WIERSMA, D. A. \& ROTH, R. A. 1980. Clearance of 5-hydroxytryptamine by rat lung and liver: the importance of relative perfusion and intrinsic clearance. J Pharmacol Exp Ther, 212, 97-102.

WORT, S. J., WOODS, M., WARNER, T. D., EVANS, T. W. \& MITCHELL, J. A. 2001. Endogenously released endothelin-1 from human pulmonary artery smooth muscle promotes cellular proliferation: relevance to pathogenesis of pulmonary hypertension and vascular remodeling. Am J Respir Cell Mol Biol, 25, 104-10.

WRIGHT, A. F., EWART, M.-A., MAIR, K., NILSEN, M., DEMPSIE, Y., LOUGHLIN, L. \& MACLEAN, M. R. 2015. Oestrogen receptor alpha in pulmonary hypertension. Cardiovascular research, 106, 206-16.

ZHENG, Y., RUSSELL, B., SCHMIERER, D. \& LAVERTY, R. 1997. The effects of aminorex and related compounds on brain monoamines and metabolites in CBA mice. J Pharm Pharmacol, 49, 8996.

ZHU, D. \& RAN, Y. 2012. Role of 15-lipoxygenase/15-hydroxyeicosatetraenoic acid in hypoxiainduced pulmonary hypertension. Journal of Physiological Sciences, 62, 163-172. 